\title{
A Somogyvármegyei Berzsenyi Irodalmi Társaság története 1904-1909
}

\author{
GÁSPÁR FERENC
}

7400 Kaposvár, Kossuth Lajos utca 10., e-mail: drgasparferenc@t-online.hu

\begin{abstract}
GÁspÁR, F.: The History of the Berzsenyi Literary Society 1904-1909.

Abstract: The Berzsenyi Literary Society (as it is called today: Dániel Berzsenyi Society of Literature and Art) was reestablished three times (in 1925, 1946 and 1985) after its foundation in 1904 . The publications elaborating the history of the Society deal exclusively with the presentation of the periods following the re-establishments, and merely mention, but do not reveal thoroughly the history of the early years of 1904-1909. The aim of the author of the present publication is to eliminate these deficiencies (to a considerable degree by making use of the contemporary local press coverage). In doing so, the study touches upon the relationship between the Berzsenyi freemason lodge of Kaposvár and the Literary Society, which relationship gave rise to suspicion among the general public and thus hindered the expansion of membership and the efficacy of functioning.
\end{abstract}

Keywords: literary programs, freemasons, prelections, unconcern

A Berzsenyi irodalmi társaság (mai nevén Berzsenyi Dániel Irodalmi és Művészeti Társaság) az 1904-ben történt megalakulását követő években további három alkalommal $(1925,1946,1985)$ is újra alakult. A társaság történetét feldolgozó közlemények kizárólag az újraalakulásokat követő időszakok bemutatásával foglalkoznak, és csupán említik, de nem végzik el a kezdeti, 1904-1909 közötti évek feltárását. Jelen közlemény szerzőjének célja ezt a hiányt (nem csekély mértékben a helyi sajtóban megjelent korabeli tudósítások felhasználásával) megszüntetni. Ennek során szól a kaposvári Berzsenyi Szabadkőműves-páholy és az irodalmi társaság közötti kapcsolatról, amely a közvélemény szemében gyanakvásra adott okot; gátolta a tagság bővülését, a működés hatékonyságát.

Pekár Gyula ${ }^{1}$ a Petőfi társaság tagja 1903 januárjában javasolta, hogy létre kellene hozni egy Országos Irodalmi Szövetséget, amelynek az összes közmüvelődési és irodalmi társulatok tagjai lennének. Terve szerint: „Az ország irodalmi és közművelődési egyletei Országos Irodalmi Szövetség elnevezésü egyesületet alkotnak, oly célból, hogy a kölcsönhatás által a) egymás hazafias akcióit támogassák, b) a magyarságot fenyegető veszélyekre egymást figyelmeztessék, s azokat közös erővel elhárítsák, c) a bárhol termő nemes eszméket közösen felkarolják, a bárhol megnyilatkozó új tehetségeket le-

1 Pekár Gyula (1866-1937) Bécsben és a Sorbonne-on tanult, öt nyelven beszélt. A Kisfaludy és a Petőfi Társaság tagja, országgyülési képviselö, államtitkár, majd miniszter. A Magyar Tudományos Akadémia levelező tagja, kora ünnepelt írója. hető hamar és országosan érvényesítsék. Az Országos Irodalmi Szövetség székhelye Budapest, de köteles minden évben másutt nagygyűlést tartani, hol tagjai mentől nagyobb számban jelenjenek meg. E nagygyűlések lehetőleg olyan helyeken tartassanak meg, melyek nagyjaink emlékéröl szenteltek, s melyeken e nagyok érdemeinek hangoztatása által a közönség közönye megtörhető és a hazafias lelkesedés elömozdítható."2 A Jókai Mór elnökségével megalakult Országos Irodalmi Szövetség 1903. november 23-ai keltezéssel arra kérte a vidéki újságok szerkesztőségeit, hogy tegyék közzé felhívását lapjaikban. Abban olvashatjuk:

„[...] Mentül magasabb műveltséget ér el az anyanyelvünk, annál bizonyosabb az, hogy élünk, hogy nemzetet és hazát alkotunk. [...] Célunk az, hogy a költészet és hasznos tudás népszerü, érthető modorban vezettessék be a magyar nép tömegébe. [...] különös feladatunknak tekintjük azon magyar hazánkfiai között terjeszteni a magyar irodalom termékeit, kik a végvidékeken, a nemzetiségek által lakott területeken, elszigetelve tartják fenn hazaszeretetben gyökerező nemzeti lelkületüket."3

Az Országos Irodalmi Szövetség célkitűzései harmonizáltak a már akkor több, mint egy évtizede működő Somogyvármegyei Közművelődési Egyesület ${ }^{4}$ küldetésével, amely célul tűzte ki, hogy „a magyar közmüvelődést és hazafias szellemet terjeszti, a Dunántúlról, illetőleg Somogy vármegyéből történő kivándorlást korlátozza, vagy a mennyiben ez lehetséges nem volna, a kivándorlást irányítja s különösen a Drávántúlra átvándorló véreinket a magyar hazfiasságban és szellemben megtartja. Első feladata tehát az, hogy teljesen magyarrá tegye Somogy vármegyét!" 5

Nyíltan ki nem mondott, de egyik tényleges célja a megye déli és keleti részén élő, mintegy a lakosság tizedrészét képező nem magyar anyanyelvű lakosság különféle módszerekkel (elsősorban az iskolai oktatásneveléssel, a magyar nyelvű irodalom terjesztésével, anyagi ösztönzéssel) megvalósuló beolvasztása. Azt, hogy ez mennyire volt sikeres, a népszámlálási adatok alapján ítélhetjük meg:

2 Az Országos Irodalmi Szövetség. Budapesti Hírlap, 1903. május 29. p. 9.

3 Tolnamegyei Közlöny 1903. november 26. p. 3

4 A Dunántúli Közművelődési Egyesület fiókegyleteként 1891-ben Tallián Béla Somogy vármegye föispánja kezdeményezésére jött létre.

5 Csánki Dezső (szerk.): Magyarország vármegyéi és városai Somogy vármegye p. 577. Országos Monográfiai Társaság Budapest, é.n. 


\begin{tabular}{|c|c|c|c|}
\hline év & a megye lakossága & $\begin{array}{c}\text { német anyanyelvűnek } \\
\text { vallja magát }\end{array}$ & horvát anyanyelvű \\
\hline 1890 & 326.835 & 19.721 & 10.829 \\
\hline 1910 & 367.859 & 18.718 & 9.934 \\
\hline
\end{tabular}

1890-ben a megyében a német-horvát anyanyelvűek az összlakosság 9.3\%-át, 1910-ben 7.8\%-át alkották (a csökkenés 1.5\%).

Abban általános egyetértés volt, hogy az asszimilációt továbbra is folytatni kell, ennek jó példája, hogy a kaposvári „Berzsenyi” szabadkőműves-páholy is átvette és Munkatervébe beillesztette a feladatot: „Elő kell mozdítanunk a magyarosodást megyénk azon helyiségeiben, melyeknek lakói nem magyar anyanyelvüek, s a Horvátországba szakadt testvéreinket is meg kell tartanunk a nemzetnek."6

Egy irodalmi társaság létrehozásának tervéről 1904 elején értesültek a kaposváriak:

„Helybeli laptársaink közlik, hogy Kaposvárott irodalmi társaságot akarnak alakítani a helybeli és megyei írók, hírlapírók, amilyen társaságok már az ország számos megyéjében müködésben vannak és pedig szép eredménnyel. Célja: a saját kebeléből is a tehetségek jó alkotásait terjeszteni. Ha egy író maga áll vállalata mellett, elporlik; ha a társaság üti rá pecsétjét, sokkal biztosabb az eredmény. Irodalmunk a magyarság millióinak erős páncéla, a külföldi sugalmazott, vagy rosszindulatú sajtó támadásai ellen! ${ }^{7}$ Tehát csak előre, fiatal barátaim! Elöre. Tömörülni, alakulni. Egy porszem is valami; a porszemek milliárdjai égig érő piramis! Dolgozni, hatni; felolvasásokat tartani; az első estvét, ha többet nem, egy égő gyertyaszállal! Hiszen nem a gyertya világa teszi meg, hanem a cél, amit a társaság szolgál; de a fény, amit terjeszt. De mielőtt az első lépést megtennék írótársaim, fontolják meg: Tudnak-e sokat türni, sokat fáradni? Kritikát, előítéletet legyőzni? Jeget olvasztani? Hogyne tudnának! Hiszen az északi sarkon még az óriás jéghegyek is megindulnak, ha rájuk süt a nap! Tehát csak elöre."

Az irodalmi kör tervezett megalakulásának hírét a közvélemény kedvezően fogadta, élénk érdeklődés mutatkozott iránta. Egy héttel később a Somogy arról tudósított, hogy Roboz István vezetésével működő tíztagú előkészítő bizottságban megkezdődött az alakuló ülésre meghívandók összeírása. ${ }^{9}$ A létesítendő irodalmi társaság mindazokat várta, akik Kaposváron, vagy a megyében „irodalmi munkásságot fejtenek ki, vagy akik igaz lélekkel pártolják a magyar irodalmat s így válnak a

6 Gáspár Ferenc: A kaposvári „Berzsenyi” Szabadkőműves-páholy. p. 83. Kaposvár, Szerzö, 2012.

7 Nincs új a nap alatt? Már akkor is? [A szerző kérdései.]

8 Roboz István: Irodalmi társaság Kaposvárott. Somogy, 1904. február 21. p. 1. Roboz István (1826-1916) a Somogy című politika és vegyes tartalmú hetilap alapítója, szerkesztője, újságírója. Élénk társadalmi és kulturális tevékenységet folytatott, költőként is ismert. A Pápai Református kollégiumban Petőfi Sándor és Jókai Mór tanulótársa, 1848-ban Noszlopy Gáspár titkára. Az 1848as eszmék mellett élete végéig kitartott.

9 A kaposvári irodalmi társaság. In: Somogy, 1904. február 28. p. 3 A feldolgozott lapok általános gyakorlata volt, hogy a bennük található tudósítások a szerzők nevének feltüntetése nélkül jelentek meg. Ennek ismételt jelzésére a továbbiakban nem térünk ki. társaság igen nagy hasznára. [...] a társaság tagjai nem csak férfiak, hanem nők is lehetnek, akik éppen olyan jogokkal fognak bírni, mint a férfi tagok. Az előkészítő bizottság úgy határozott, hogy még a hét folyamán száz tagú szervező értekezletet hív össze az új városháza nagy termébe [...] Ez a száz tagú nagy bizottság határozza el, hogy városunk és vármegyénk társadalmából mily számmal vonja az új tagokat a társaság kebelére. Valószínű - az az eddigi jelekből ítélve, hogy az irodalmi társaságnak több, mint 500 tagja lesz."10

Április végére már biztossá válik a megalakulás lehetősége, mert az Országos Irodalmi Szövetség, amely a Dunántúlon három „erősséget” (Győr, Pécs, Kaposvár) kívánt létrehozni, szellemi és anyagi támogatásáról biztosítja a szervezőket. Ezzel egyidejűleg megkezdi működését az alapszabály előkészítő bizottság. ${ }^{11} \mathrm{Hoz}$ závetőlegesen egy hónap alatt elkészül az Alapszabály (a Függelékben közölve), május első napjaiban kiküldik a meghívókat a május 15-én 15 órakor a Városháza dísztermében tartandó alakuló közgyülésre. ${ }^{12}$

A Somogy címü lapban május 8-án a következő felhívás jelenik meg: „Felhívás Somogymegye irodalompártoló közönségéhez. Somogyban egy az egész vármegyére kiterjedő irodalmi társaság van alakulóban, mely a megyei írókat, szónokokat és az egész irodalompártoló közönséget lesz hivatva nemes törekvésben egyesíteni. A cél szép, fenséges, és hazafias! Minden szépért és jóért lelkesedni tudó fia e megyének szívéből örülhet, ha sikerül meggyújtanunk azt a fáklyát, amelyhez a lángot közéletünk, társadalmunk minden tettre kész tagjának szítani szent kötelessége. Mert mi az irodalmi táraság hivatása? Kezdő tehetségeket felfedezni, nevelni az irodalomnak. A könyvirodalmat megkedveltetni, terjeszteni, hogy az általa és benne a múveltséget és idealizmust hintsük a lelkekbe. Irodalmi nagyjaink nevét, müveit minél ismertebbekké tenni. Egy Eötvös br., Vörösmarty, Arany, Petőfi nevei messzebb hangzanak, mint bármily nagy acél ágyúé; ez öl, rombol, amaz ellenben termékenyít, világosságot visz mindenfelé. Célja: saját kebeléből is tehetségek jó alkotásait terjeszteni, mert ha egy kezdő író csak maga áll vállalata mellett, elporlik, ha egy társaság üti rá pecsétjét, sokkal biztosabb az eredmény. Felkutatni Somogy nagyjait a múltban, s emléküknek világot gyújtani, sírjaikat a kegyelet virágaival beültetni: egy Zrínyinek a költőnek, Berzsenyinek, Csokonaiak lánglelkét, amelyek egykor a megye büszkeségei voltak, új életre kelteni. Egybegyűjteni Somogy megye azon élő

10 A kaposvári irodalmi társaság. In: Somogy 1904. március 27. p. 3. Az irodalmi társaság várható taglétszámára vonatkozó, túlzott lelkesedésből fakadó becslés nem volt reális célkitüzés.

11 Az irodalmi társaság. In: Somogy, 1904. április 24. p. 2. (A lap megfogalmazása szerint Kaposvárt „meg kell erősíteni egy irodalmi központ által".)

12 Kész az alapszabály. In: Somogy, 1904. május 1. p. 2. 
nagyjait, kik bár elszakadtak szülőmegyéjüktöl, lelkükben még Somogyhoz vannak láncolva és szívesen áldoznak azon az oltáron, amelyet régi otthonukban földijeik emelnek. Fölkeresni a költészet azon gazdag kincsesbányáit, amelyekben a somogyi népköltészet örökbecsü, de könynyen veszendőbe menő termékei vannak összehalmozódva, s megmenteni a nemzetnek e nagyértékủ szellemi vagyonát, hogy ezzel is hozzájáruljon a műköltészetnek megnemesedéséhez és igaz magyar szellemben való fejlődéséhez. Célja felolvasásokkal szórakoztatni a közönséget, mert egy írói gárda működésében mindig van bizonyos inger, hatás, mely tüzel, érdeklődést kelt. Aztán mindenekfölött az irodalomban nyelvünket szolgálni, mely kincsünk, talizmánunk, s mindenünk! A magyar irodalom az a nemzetnek, ami a nap a tenyészetnek, az életnek: világít, érlel, termékenyít. Irodalmunk a magyarság millióinak erős páncélja: védi nevünket, dicsőségünket, történelmi múltunkat. Ime, csak csepp a tengerből: néhány részlet az irodalmi társaság hivatásából. Előre hát! Tömörüljünk, alakuljunk! Egy porszem is valami; a porszemek milliárdjai égig érő piramis! Somogy egyik legrégibb, s mindig vezér vármegyéje volt az országnak: az első Árpádok okleveleiben már ott találjuk; ez a föld, hol Kupa a nemzeti ellenállás zászlóját felemelte, mely látta IV. Béla bujdosását, mely az egész ország helyett elszenvedte a török harcok legerősebb viharait. Itt buzdult dalra a lánglelkü Csokonai, itt élte remete életét a romlásnak indult nemzetért tettre serkentő Berzsenyi Dániel, itt rengett bölcsője a szelíd, de fennkölt lelkű Virág Benedeknek. Lakosságának ősi erényei mindig tündököltek - bizonyára most is ott lesz egy irodalmi nagykeresztelésen, midőn szépért hevülő fiai a művelődés, édes nyelvünk oltárainál meggyújtják az áldozat tüzét! Tömörüljünk minél számosabban a felemelt zászló alá, s az eszmének győzni kell! Gondoljunk a legnagyobb magyar idealista jelmondatára: Nyelvében él a nemzet. Kaposvár, 1904. május 1, az 1904. április 18-án tartott nagy előértekezlet megbízásából: Roboz István elnök. Dr. Pete Márton jegyző" "13

Május 15-én a városháza dísztermében az alakuló ülést Roboz István az alapszabály-tervezet előkészítő bizottság elnöke nyitotta meg, majd mondott ünnepi beszédet. Azt követően Szundy Károly, az Országos Irodalmi Szövetség főtitkára ígért támogatást a szövetség nevében.

Dr. Pete Márton az értekezlet és az alapszabály előkészítő bizottságának jegyzője tett jelentést, amit beható vitát követően csekély módosítással elfogadtak. Beszédéből csak két fontos mondatot idézünk, amelyek értelmezésére a későbbiekben térünk ki: „[...] Miként a régi fegyvertársakat, bennünket is lánc füzzön össze úgy, hogy az elmaradót is magunkkal ragadjuk lelkesedésünk vonzó láncain! Az összetartás legyen jelszavunk, s a kitartás legyen küzdő fegyverünk!" Megválasztották a tisztikart és a rendes tagokat (ez utóbbiak névsorát az Függelékben közlöm):

13 Felhívás Somogymegye irodalompártoló közönségéhez. In: Somogy, 1904. május 8. p. 2-3. A Felhíváson szerepel az előkészítő bizottság tagjainak felsorolása is, ők 26 -an vannak. Rendes tagokká válnak, a későbbiekben nevesítem őket.

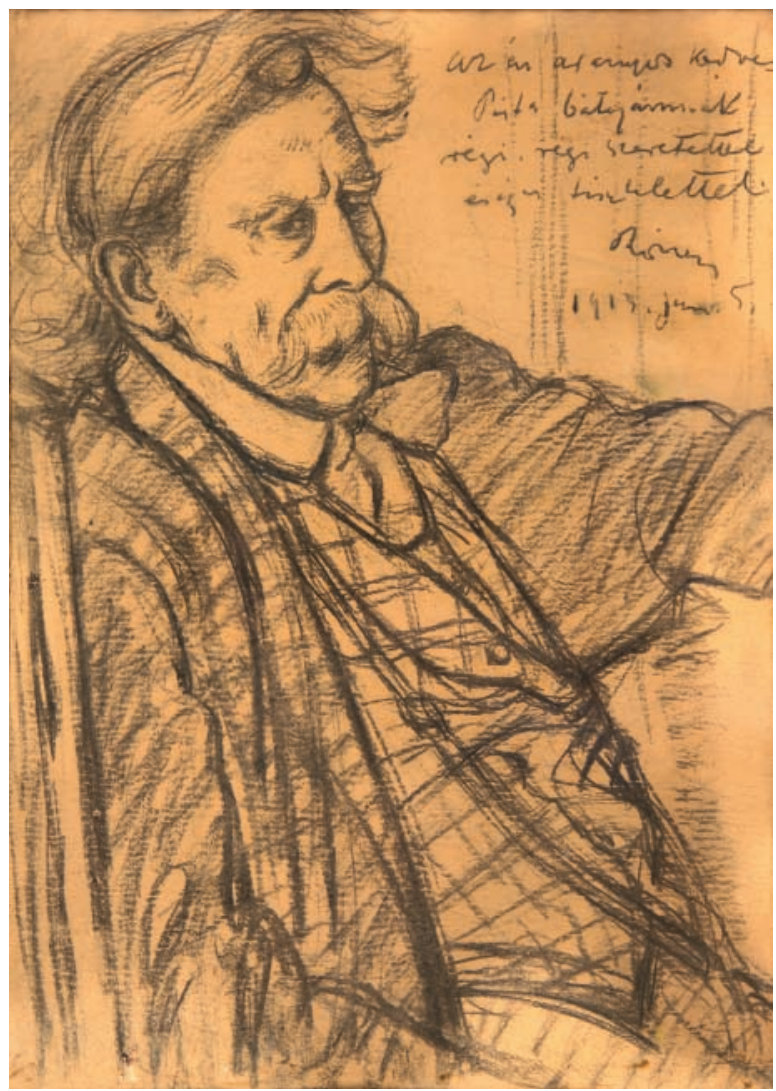

1. ábra. Rippl-Rónai József: Roboz István arcképe

elnök: Roboz István

alelnökök: Szalay Fruzina és dr. Andorka Elek

főtitkár: dr. Pete Márton

titkár: dr. Kohlbach Bertalan

pénztáros: Psík Andor

ellenőr: Noszlopy Tivadar

ügyész: dr. Csonka Ede

Az ünnepség az üdvözlő táviratok és levelek felolvasásával ért véget. Az eseményről szóló tudósítás címében első ízben találkozunk az Alapszabálynak megfelelő Somogyvármegyei Bezsenyi irodalmi társaság megnevezéssel. A társaság névhasználata a sajtóban kaotikus volt: Kaposvári irodalmi társaság, Irodalmi kör, Somogyvármegyei irodalmi társaság, Somogyvármegyei Berzsenyi társaság, Somogyvármegyei Berzsenyi kör. Ez a jelenség a későbbiekben is gyakorta ismétlődik. ${ }^{14}$

A megyehatáron túli első szereplés az Országos Irodalmi Szövetség meghívására történt, a Vas Gereben-emléktábla avatásán és emlékünnepségen (1904. június 19., Fürged, szülöház), amelyen a társaságot Pete Márton képviselte. A Somogy részletesen beszámolt az eseményröl. ${ }^{15}$ Szeptemberben a lapok ismételten közlik, hogy a társaság alapszabályát a belügy-

14 A „Somogyvármegyei Berzsenyi társaság” megalakulása. In: Somogy, 1904. május 22. p. 1.

15 Somogy, 1904. június 12.; és június 26. p.1. Vas Gereben (1823$1868)$ jogász, újságíró, lapszerkesztő. Népszerüsége és kedveltsége saját korában Jókaiéval vetekedett. 
miniszter jóváhagyta és buzdítják a nagyközönséget a közremüködésre. ${ }^{16}$

A szeptember 17-én megtartott rendkívüli ülésén határozatot hoznak arról, hogy a (szóhasználatuk szerint) bemutató ülést a városháza dísztermében október 23-án tartják meg. ${ }^{17} \mathrm{Az}$ eseményről a Somogy három oldalán végigfutó, részletes tudósítás olvasható. ${ }^{18} A$ város már kora reggel fel volt lobogózva, a városháza díszterme felvirágozva. A meghívott díszvendéget Rákosi Jenőt ${ }^{19}$ szállásáról, a Korona szállóból Andorka Elek alelnök vezetésével egy háromtagú küldöttség kísérte át a városházára. Az ajtóban Tallián Gyula főispán, Sárközy Béla alispán, Németh István polgármester, Melhárd Gyula esperes, Szalay Károly és a notabilitások várták. Németh István üdvözlöbeszédet mondott. Az elnöki asztalnál Roboz István, Rákosi Jenő, Kohlbach Bertalan, Endrei Ákos, Szalay Fruzina foglaltak helyet. Az ülés programját a Függelékben közlöm. A Korona szállóban 70 fő részvételével társas ebédet rendeztek, amelyen a híres prímás, Szimpliciusz (Barcza József) és zenekara muzsikált. A pohárköszöntők sorát Berzsenyi Gerő nyitotta meg, őt követte Rákosi Jenő, Szalay Károly, Tallián Gyula, Melhárd Gyula, és Szabó Kálmán. Az emelkedett hangú tudósítás különös utóhanggal zárul, amely akár próféciának is felfogható: [...],Ebbe az öröm és méztengerbe néhány ürömcsepp is vegyült! Az ünnepi hangulatot most nem akarjuk semmi sötét színnel zavarni; de alkalmilag rovásra jön, mert elhallgatni kár volna! A társaság lelkesedését nem alterálja ugyan, de mint jellemző dolgokat kötelességünk lesz felemlíteni. Hiszen nem egy zsenge társasággal, de Julius Caesarral is megtörtént, hogy midőn koszorú garmadák közt haladt az ujjongó tömeg útjában, egy polgár a gombját varrta fel.

- Hát te nem látod a hőst? - dörgött a hömpölygő népáradat.

- Engem az ilyféle nem érdekel - szólt a profán ember -, látjátok, hogy a gombomat varrom!"

A másik helyi lap, a Kaposvár is vezércikkben tudósít az eseményről: „Fontos és messze kiható kultúrünnepre virradt ma városunk, és vármegyénk

16 A Somogyvármegyei Somogy, 1904. szeptember 11. p. 2.; 18. p. 2.

17 A Somogyvármegyei Berzsenyi irodalmi társaság. In: Somogy, 1904. szeptember 25. p. 2.

$18 \mathrm{Az}$ irodalmi társaság ünnepe. In: Somogy, 1904. október 30. p. 1-3. Más forrás (Somogyi Ujság, 1904. október 26. p. 2.) „első díszülés"-nek nevezi.

19 Rákosi Jenő (1842-1929) író, újságíró, színházigazgató, lapszerkesztő, förendiházi tag, a Magyar Tudományos Akadémia levelező, a Kisfaludy Társaság rendes és a Petőfi Társaság tiszteletbel tagja. Elutasította az általános választójog bevezetésének baloldali követelését, mert az ország nyugalmát és területi épségét féltette töle. Az ország magyarosodását a jog és a kultúra alkotmányos eszközeivel kívánta elérni. Álma a harmincmillió magyar által lakott magyar birodalom gondolata volt, amely nemcsak a szláv, hanem az Európára ugyancsak veszélyt jelentő német túlsúlynak is ellenerőt jelentett volna. (Forrás: Wikipedia) Megítélése napjainkban ellentmondásokkal terhelt, végletekig kiélezett. (Érdemes összevetni Pintér Jenő Magyar Irodalomtörténet A magyar irodalom a XIX. század utolsó harmadában, Budapest, 1934 és Hegedüs Géza: Irodalmi arcképcsarnok A magyar irodalom arcképcsarnoka Budapest, 1976 köteteiben található értékeléseket.) Ennek ellenére, vagy inkább ezzel együtt, nem lenne idegen feladat a mai Berzsenyi Irodalmi és Müvészeti Társaságtól a személyével való tárgyilagos szembenézés. magyar népe. A nemzeti művelődésnek készülnek ma oltárt emelni azok, kik felfogván a nemzeti eszmének és az ideális gondolkozás terjedésének csodálatos öszszeforrasztó és nemesítő erejét, egy, működésében az egész vármegyére kiterjedő, irodalmi egyesületet alapítottak, a megye egyik legmagasztosabban gondolkodó fiának, Berzsenyi Dánielnek égisze alatt. Az oltár tüzének élesztéséhez hozzájárulni nemes honfiúi lelkesedésünkkel, eljönnek hozzánk az ország különböző részeiből a hasonló célú egyesületek küldöttei élükön Rákosi Jenővel, a magyar hírlapírói gárda lánglelkű vezérével. Nagy jelentőségű városunkra és vármegyénkre nézve a kulturális ünnep nemcsak azért, mivel hozzájárul szellemi életünk fellendítéséhez és ismét összehoz mindnyájunkat egy táborba, egy nemes eszme kultiválására, bennünket, kik sokszor különböző utakon járunk. Fontos azért is, mivel a magyar szellem, a magyar nemzetiség megerősítését szolgálja. Ma már mindnyájan meg vagyunk győződve arról, hogy nemcsak oly vidéken kell a magyar kultúra terjesztésére törekedni, ahol idegen nemzetiségek fenyegetik az uralkodni hivatott és rendelt magyar nemzet életfáját, hanem még sokkal inkább ott, ahol a magyar faj uralkodik s éppen veszélytelensége tudatában könnyen elbizakodik s elhanyagolja nemzeti kultúráját. A kozmopolitizmus veszedelme sehol nem üthet könnyebben rést a nemzeti kultúrán, mint ott, ahol azt nem kell féltenünk. És ezért örömmel üdvözöljük Somogy megyében a nemzeti művelődésnek mai nappal felépítendő új védőbástyáját. Rajta leszünk, hogy közönségünk állandó érdeklődésének tárgy legyen e nem es irányú egyesület. Annak tagjait pedig arra kérjük, hogy őrizzék meg a szent ügy iránti lelkesedésüket állandóan, s a társaság szellemét tegyék méltóvá ama nagy magyar emlékéhez, kinek nevét zászlójukra írták, s ki azt hirdette: Megyek rendeltetésem pályafutásain, A szebb s nemesebb lelkeknek útján."20

A lapban csak eldugott helyen szerepelt, hogy az ülést megelőző tagválasztás során tagokká lettek: dr. Szabó Kálmán (volt kaposvári polgármester és országgyülési képviselő, taglalt időszakunkban ügyvéd), Dömény József lelkész, Pap János tanító, és felolvasták Kiss József, Pekár Gyula és Endrődi Sándor köszönő levelét, abból az alkalomból, hogy őket a Berzsenyi irodalmi társaság tiszteletbeli tagjává megválasztották.

Az ünnepi ülésről szóló tudósítást olvasva azt gondolhatnánk, minden a legnagyobb rendben van. A valóság ennél árnyaltabb, mert az emelkedett hangulat elmúltával, egy héttel később ugyanezen lap így kesereg: „A kört igen helyesen nem a városnak, de az egész megyének csinálták. A városi ünnepről a vidék teljesen hiányzott. Csak két Berzsenyi rokon volt jelen vidékről. Nem arról van szó, hogy pártolja-e a vidék a kaposvári kört, hanem arról, van-e a vármegyének olyan közönsége, amelynek az ilyenféle dolgokban való részvétel lelki szükséglete."21

20 Berzsenyi társaság. In: Kaposvár 1904. október 23. p. 1.

21 A Berzsenyi kör ünnepélyéröl Egy kellemetlen ügy. In: Kaposvár, 1904. október 30. p. 3. 
November végén a Somogyvármegyei Berzsenyi irodalmi társaság közhírré teszi, hogy az Alapszabályban meghatározott módon átvehető az Országos Irodalmi Szövetség Évkönyve, továbbá a Szövetség kiadványai közül „,irodalmi jeleseinktől” öt további könyv, ami már önmagában is „többet ér a tagdíjnál”. Felszólítja a pártoló tagokat a könyvek átvételére. A közleményt már átlengi bizonyos keserüség, amikor egyúttal szóvá teszi, hogy kicsi a taglétszám, pedig egy „kirándulásért, vagy pár órás bankettért ennek az összegnek többszörösét fizetik, és azon 2-300 egyén is részt vesz". ${ }^{22}$

December 4-én megtartották az évi rendes ülést a városháza nagytermében. Két felolvasásra is sor került. Danka István: Novella és Melhárd Gyula (esperes plébános): Czindery Pál, somogyi követnek kizárása az 1796-ik évi országgyűlésből. „Szép közönség volt, de sajnos nem akkora amilyent a két élvezetes felolvasás megérdemelt volna”. ${ }^{23}$ A Somogyi Ujság egyértelmübben fogalmaz: „Sajnos, hogy ezen a minden ízében érdekes gyülésen oly csekély számban jelent meg a közönség, hogy e felett csodálkozásunkat kell kifejeznünk."24

A Somogymegyei Berzsenyi irodalmi társaság 1905. január 15-én Szabó Kálmán elnökletével tartotta meg évi közgyűlését. „Midőn május havának lelkes felhívásra a városháza nagytermében gyülekezett Kaposvár áldozatkész közönsége, nem sejtette volna senki, hogy az első közgyűlésen a titkári jelentés beteg, tespedt szervezetről fog szólni. [...] a vármegye és a kaposvári közönség közönye dermesztő fagyként hat e még zsenge palántára, viszonya az Országos Irodalmi Szövetséghez anyagilag sorvasztja a társaságnak ma még igen csekély jövedelmét. Az alapításkor 62 tag között csak 44 tett eleget kötelességének. A társasággal szemben tanúsított közönyt azzal indokolja egyik is, másik is, hogy a S.B.I.T. [sic!] a szabadkőmüvesek alkotása és mint ilyen intézményt nem támogathatja. Nos hát ez nem ál!!

Az irodalmi társaságban sem Roboz István, sem Kisfaludy Attala nem szabadkőművesek pedig ezek alkották meg; és ha lesz [helyesebben: van! G.F.] a rendes tagjai között ily tag, az inkább előnye, mint hátránya lehet a társaságnak, mert ezek az urak - köztudomás szerint - minden jó ügyben fáradoznak és ami irodalmi társaságban a fő - dolgoznak. ${ }^{25}$ [Kiemelések az eredetiben.]

A közönséghez fordulunk! támogassa a S.B.I.T.-ot [sic!] melynek céljai, törekvései tisztán magyar nemzetiek, lépjenek be pártoló tagoknak, látogassák meg a felolvasást, hogy ne ismétlődjön meg ama szégyen-

22 A Somogyvármegyei Berzsenyi irodalmi társaság. In: Somogy, 1904. november 27. p. 2.

23 Az irodalmi társaság első felolvasó ülésén. In: Somogy, 1904. december 11. p. 3

24 Felolvasó ülés. In: Somogyi Ujság, 1904. december 14. p. 3.

25 Roboz István valóban nem volt szabadkőműves, Kisfaludy Attala meg nem is lehetett az, mert a páholyba nőket nem vettek fel! Teljes joggal nevesíthette tehát őket az írás szerzője. Ezzel együtt a cáfolatban szereplő „ezek az urak” kitétel tipikus freudi elszólás (azaz egy rejtett gondolat akaratunk ellenére a felszínre tör és okoz gyakorta kellemetlenséget), ugyanis „ezek az urak” már jelen voltak a Berzsenyi irodalmi társaság tagjai között. letes helyzet, hogy felolvasó ülését üres teremben tartja, mint történt múlt vasárnap, midőn Roboz István és Pete Márton dr. 30 ember előtt, (köztük 5 hölgy és 2 polgári iskolai leányka) tartotta meg székfoglalóját." Pontosabban: a beteg Roboz István helyett Kohlbach Bertalan titkár olvasta fel a Toll című dolgozatot, majd Pete Márton szavalt el saját verseiből néhányat. ${ }^{26}$

A Kaposvár címü lapban Noszlopy Tivadar kesereg. „Nem értem azt a nagy közömbösséget, amelyet a vármegye és székvárosunk Kaposvár részéről ez új irodalmi társulattal szemben látok. Pedig az ünnepélyes megnyitásból ítélve abban a hitben voltam, hogy társulatunk csakhamar virágzásnak fog indulni. Alapító, különösen a pártoló tagok szép számban jelentkeztek, de azóta csend és nyugalom! A társaság tagjai érdekes felolvasásokat tartanak, mégis, amíg a megnyitó ünnepélyen a városház nagytermét zsúfolásig megtöltötte a városi és vidéki előkelő közönség; a második ülésen a múlt év december havában oly csekély számban voltak jelen, hogy ennek okát elképzelni nem tudom. [...] A mi különleges nemzeti viszonyaink mellett nagyon meg kell becsülni az irodalmi társaságokat, amelyek édes magyar nyelvünk fejlesztését s irodalmunk művelését tüzték feladatul! A Somogyvármegyei Berzsenyi Irodalmi Társaság is, mely egy nagy névhez van füzve, lehetetlen, hogy a közönség áldozatául essék! Noszlopy Tivadar"27

Ezen a ponton kitérőt kell tennünk, hogy értelmezni tudjuk a Somogy szabadkőmüvességgel kapcsolatos felvetését. Úgy tűnik, a városban nem maradt titokban a szabadkőműves páholy létezése. Már 1903ban, a Zenekedvelők Egyesülete megalakulásánál kibontakozott vitában - miszerint a városban túl sok egyesület alakul és működik ${ }^{28}$, amelyek megosztják az érdeklődőket, a szabadkőmüvesek lapjának tekinthető Kaposvárban megjelent írás lábjegyzetében a szabadkőműves szerkesztő, a Zenekedvelők Egyesü-

26 A Somogymegyei Berzsenyi Irodalmi társaság. In: Somogy, 1905. január 22. p. 1. A Toll című írásában Roboz arról elmélkedik, miként vált az (írói) toll hatalommá. Teljes terjedelemben közölve: Somogy, 1905. február 5. p. 1-2. Pete Máron székfoglalóján elhangzott verseket a Somogyvármegye című lap közli: 1905. június 5. p. 1.

27 A ,Somogyvármegyei Berzsenyi Irodalmi Társaság”. In: Kaposvár, 1905. Január 26. p. 2. Noszlopy Tivadar (1861-1916) vármegyei főjegyző, Berzsenyi távoli rokona. Hírlapíró, költő. Számos munkájában foglalkozik Berzsenyi, életével, munkásságával, ápolja emlékét.

28 A helyzet és az arról való vélekedés három évtized múltával sem változik, úgy tủnik, ez a jelenség végigkíséri a megyeszékhely történetét. „Városunknak több, mint száz különböző célú és értékü egyesülete van és mindegyik azt ambicionálja, hogy a tagok számát és így a jövedelmet illetően ő legyen az első. Senkinek nem akarják megengedni nálunk, hogy négy-öt egyesületnél kevesebben legyenek érdekelve. Kaposvár lakóinak igen tekintélyes része elvérzik a tagdíjakon, és örökre meghal a kultúra számára. Ehhez járul a sok anyagi és egyéb gond, a szórakozásnak a tanulás fölé helyezése, a kényelmes nemtörödömség, a klikkek áskálódása, a sok sok személyes sérelem, a mellőzöttség bosszúja, a kellő figyelem és propaganda hiánya, a jó, vagy rossz időjárás, a feledékenység, a más irányba való elfoglaltság és még százféle ürügy és mentegetözés, ami ellen nincs orvosság, és amibe bele kell törődni." Hetyey József: Kaposvár, mint kultúrközpont. Berzsenyi Társaság propaganda kiadása, Kaposvár 1937. p. 12. 
lete vonatkozásában megjegyzi: „Jól értesült egyének még - uramfia! - holmi szabadkömüves-páholyról is beszélnek. Bár igazuk lenne!"29 Le meri írni mindezt, amikor ő tudja a legjobban, hogy a páholy munkatervében feladatként szereplő szerelő „zenekedvelő kör” létrehozásának gyakorlati megvalósulása a Zenekedvelök Egyesülete, amelynek alelnöke dr. Müller Nándor a Berzsenyi Szabadkőműves-páholy főmestere, és a 24 tagú választmányában nyolc páholytag van. ${ }^{30}$

A páholy Munkatervében szerepelt, hogy „elő kell segítenünk egy irodalmi egyesület alakítását." ${ }^{11}$

Az irodalmi társaság létrehozása profán (nem szabadkőmüves) körökben fogalmazódott meg, de mivel annak céljai nem voltak ellentétesek a páholyban uralkodó szemlélettel, 1904. március 18-án páholyhatározat született annak támogatásáról. A Somogyvármegyei Berzsenyi irodalmi társaság megalakulásakor már az előkészítő bizottságban is négy szabadkőmüves volt, később öten lettek rendes tagok. A szabadkőmüves-jelenléttel kapcsolatos szóbeszéd folyamatosan jelen volt a városban, és az értelmiség azon része, amelyet egy irodalmi társaság léte egyáltalán megérintett, ha nem is ellenségesen, de gyanakvással fogadott minden olyan hírt vagy jelenséget, amely mögött a rejtélyes szabadkőmüvességet lehetett sejteni. Ez indította dr. Kohlbach Bertalant ${ }^{32}$ a fögimnázium tanárát, a társaság titkárát egy általa lehetségesnek vélt megoldás javasolására.

A továbbiakban beszéljenek a Berzsenyi Szabadkőműves- páholy dokumentumai. Részlet a páholy május 20-ai ülésének Jegyzőkönyvéböl: „Főmester testvér jelenti, hogy az alakulóban lévő szépirodalmi társaság titkára felkérte őt, hogy alkalmas módon, valamelyik hírlapban nyilatkozzék a páholy, hogy a szépirodalmi szabadkömüvesek kezdeményezésére létesült, mert profán körök egy része vonakodik a társaságba tagnak belépni, miután azt hiszi, hogy az szabadkőmüvesi alkotás. Ajánlja testvéreknek a kérdés beható tárgyalását. Fekete [Gyula] testvér ellenzi, hogy akár a páholy, akár valamelyik testvér ezen kérdésben hírlap útján nyilatkozzék; szerinte a támadás csak provokáció akar lenni, hogy ez a páholyt nyilvános nyilatkozatra bírja. Nekünk - úgymond - a titokzatosság a legnagyszerübb fegyverünk, amelyböl ez idő szerint kilépnünk nem szabad. Szerinte az, aki fenti ok miatt nem lép a szépirodalmi társaságba, az nem odavaló amúgy sem. Bízok

29 Egyesületeink. In: Kaposvár, 1903. október 8. p. 1-2.

30 Gáspár: i. m. p. 84., p. 97.

31 Uo. p. 83

32 Kohlbach Bertalan (1866-1944). Személyével részletesebben is foglalkozunk. Dr. Kohlbach Bertalan ekkor már tíz éve a főgimnázium tanára volt, a történeti és földrajzi múzeum őre, az országos régészeti és embertani társaság választmányi tagja, a magyar néprajzi és pedagógiai társaság és a kaposvári polgári iskolai egyesület választmányi tagja. 1897-ben képesítést szerzett latin és német nyelvből, bölcsészdoktori oklevelet 1888-ban német, a perzsa és a keleti (arab, szír, héber) nyelvekből. Számos tudományos és néprajzi témájú közleménye jelent meg különféle hazai és német folyóiratokban. Két alkalommal is sikertelenü kérte felvételét a „Berzsenyi” Szabadkőmüves-páholyba, a második, immár végleges elutasítására 1905. február 17-én került sor. A következö tanévtöl már Körmöcbányán tanít az ottani Állam Föreáliskolában. A történésekröl és az elutasítás indoklásáról bövebben: Gáspár: i.m. p. 186-191. a Somogy megyei közönségben, hogy a szépirodalmi társaság ügyét nem fogja elejteni." ${ }^{33}$

Vita alakul ki, amelyben erösen megoszlanak a vélemények: Papp Kálmán cáfoló nyilatkozat megjelentetését ajánlja, amelyet úgy kell megfogalmazni, hogy egyúttal belépésre buzdítson. [!] Faragó Lajos Feketével ért egyet: „Nem akar precedenst nyújtani arra, hogy a páholyt néhány hecckedvelő ember provokálása nyilvános nyilatkozattételre bírja. Legyen ez eröpróbája a páholynak." Összefoglalójában Müller Nándor fömester támogatja a cáfolást, de a szavazásnál kisebbségben marad. ${ }^{34}$

Elgondolkodtató az is, hogy a szépirodalmi társaság részéröl a kérést felvető titkár az a Kohlbach Bertalan volt, aki akkor már maga is kacérkodott a páholytagság gondolatával. Érdekes Fekete indokolatlanul heves reakciója, aki egyenesen a szabadkőmüvesség elleni „támadásnak” minősíti azt. Nehezen megválaszolható, hogy Kohlbach talán csak attól tartott, hogy a szabadkőművesség rátelepszik egy jó kezdeményezésre, és attól kezdve majd sajátjaként kezeli azt?

Ez a kérdés általános érvényü lehet számos egyesület, jótékonysági akció esetében, napjainkig ható dilemmákkal, ugyanis az igazsághoz hozzátartozik, hogy gyakorta profánokkal végeztetett el a szövetség minden ízében szabadkőműves-munkát. Hogy aztán ennek a páholyhatározatnak mi volt a hozadéka, öszszességében nehéz megítélni.

A szabadkőművesektől nem áltt távol, hogy a folyamatokban, történésekben való jelenlétüket csak a szövetség beavatott tagjai számára érthető üzenetekkel jelezzék (hitelesítsék, nyugtázzák) sajátjukként. Most kell emlékezzünk a Berzsenyi irodalmi társaság alakuló ülésén Pete Márton (leendő) páholytag korábban idézett mondataira. Az abban szereplő lánc a szabadkőművesség számára fontos szimbolikus tartalommal rendelkezik, ugyanis a szövetség fiai önmagukat a szövetség láncszemeinek tekintik. Másik vonatkozásában a páholymunkák fontos, ünnepélyes mozzanata a „láncbeszéd”, ${ }^{35}$ amikor az összetartozást kört alkotó összekapaszkodással szimbolizálják az elhangzó beszéd tartama alatt. Hasonló üzenetet hordoz az is, hogy az ugyanerröl az eseményröl a Kaposvárban megjelent tudósítás az irodalmi társaság addig szokásosan használt jelmondata helyett („Nyelvében él a nemzet!"36) a szabadkömüves-páholy jelmondatának idézésével, Berzsenyi soraival zárul:

"Megyek rendeltetésem pályafutásain,

A szebb s nemesebb lelkeknek útján."

A véletlen egybeesés lehetőségét kizárja, hogy a Kaposvárban megjelent írás annak az Endrei Ákosnak tollából származik, aki a Berzsenyi Szabadkőműves-

33 Gáspár: i. m. p. 116

34 Uo.

35 Szép példája ennek Kosztolányi Dezső Láncverse, amelyet egy páholyülésen olvasott fel egy társa emlékének áldozva.

36 A Nyelvében él a nemzet! mondat szerzőjének kilétét széleskörü tudományos kutatások próbálják kideríteni. Átfogóan: Peter Sherwood: Adalékok a Nyelvében él a nemzet szállóige kialakulásához. Szó és szólásmagyarázatok. In: Magyar Nyelv 115. évf. 1.; 2019. tavasz, p. 78. 
páholy alapító tagjaként nemcsak a munkaprogram megalkotója (abban szerepelt egy irodalmi társaság létrehozása), hanem a páholy jelmondatának kiválasztója is. Az irodalmi társaság megalakulását a testvérek saját személyes sikerükként élték meg és ennek a maguk módján hangot is adtak.

Foglalkoznunk kell azzal a logikusan felmerülő kérdéssel, szabadkőműves volt-e Berzsenyi Dániel, ezért választotta névadójául és „védszelleméül” a páholy? A választ Kazinczyval kell kezdenünk.

Kazinczy Ferencet 1784. január 16-án avatták az „Erényes kozmopolitához” címzett miskolci páholy tagjává. Egy tanulmány szerzőjének csillogó szóhasználata szerint ${ }^{37}$ „az akkor még szalonképes szabadkőmüvesség" összejöveteleit nyelvújító irodalmi körnek, müvelődési fórumnak tekintette. 1804 augusztusában felségül veszi a rózsakeresztes, okkult tudományokkal foglalkozó gróf Török Lajos leányát. Apósa három szabadkőműves-páholy alapítója és főmestere is volt: ezzel hallgatólagosan, de elfogadottan rásugárzik annak „fényessége”. (A „fényesség” a szabadkőművesmozgalomban a vezető tisztségviselők megnevezése.) Berzsenyi Kazinczyhoz 1810. április 8-án írott levelében utóiratként egy kérdést, kérést fogalmaz meg: „Szeretném tudni, mi a kőmívesek fája."38

A válasz Széphalmon, 1810. augusztus 26-án kelt (szöveghủen közölve): „Az a fa, a'melly eránt tudakolódól, az a' acatia. Így is határ nélkül szeretlek. Ha nem volt volna már szükséged a' kérdést tenni, még inkább szerettelek volna. Ültess egyet a' jövő télben (Január 16dikán) vagy ez ősszel (Novemb. 11d.), s nevezd az én fámnak. Az utolsóbb házasságomnak 6dikszor előforduló innepe, az első 27dike annak az estvének, a' mely oda vezetett a' hol az a' fa terem. Szegény Ipam akkor estve nyomta ott reám az első csókot és az a' nagy ember, a' ki Diaetákon [rendi országgyülés ] és most a' Septemviratuson [legfőbb ítélőszék G.F.] első ember."39

A „Még inkább szerettelek volna” finom utalás arra, hogy Kazinczy úgy vélte, Berzsenyi is szabadkőműves, de a kérdés nyomán tudatosult benne, hogy Berzsenyi nem ismeri a szabadkőművességnek ezt a szimbolikus jelképét. Ennek ellenére elég óvatlanul felfedi két „avatójának” kilétét. A hivatkozott akác nem a mi általunk ismert akácfa, az csak jóval később került át Amerikából Európába. Arról a fáról van szó, amelylyel a szabadkőműves-legendárium szerint a gyilkosság áldozatává vált Hiram Abif, a jeruzsálemi szentély építőmesterének sírját jelölték meg. Esetünkben a palesztin akác, a sittimfa a mimózafélék alcsaládjába tartozó pusztai akáciáról beszélhetünk. Ezt a fát használták a frigyláda elkészítése során is.

37 Szathmáry-Király Ágnes: A szabadkőműves Kazinczy. Magyar Múzeumok Online. A Pulszky Társaság - Magyar Múzeumi Egyesület internetes folyóirata, 2014. 02. 25.

38 Berzsenyi Dániel Levelezése, 1705. számú levél. Kiad. Fórizs Gergely, a latin szövegeket ford. Balogh Piroska, Bp.: Editio Princeps Kiadó, 2014 (Berzsenyi Dániel Összes Munkái: Kritikai kiadás). Berzsenyi tudta, hogy Kazinczy szabadkőműves.

39 Uo. 1825. számú levél
Ideillőnek tartom, hogy megemlékezzünk „a niklai remete” emlékének őrzését szolgáló történésekről, amelyet Hortobágyi Ágost a következőkben foglalt össze:

„Berzsenyi emlékének megörökítése igénye Somogyból indult ki:

1./ Somogy vármegyének 1843. május 1-én Kaposvárott tartott nagygyűlésén Döbrentei Gábor kerületi főbiztos és Somogy vármegye táblabírája indítványára elhatároztatott, hogy Berzsenyi Dániel mellszobra a nemzeti múzeumban leendő elhelyezés végett elkészíttetik, s esetleg hamvai fölé emlékkő is tétetik, aláírási ív nyittatván, azonnal 400 frt. gyűlt össze; a további gyűjtéssel: Somssich Pál, Döbrentei Gábor, és Záborszky Imre lettek megbízva. (Somogy vármegye nagy levéltárának 1843 évi prototokolluma, 458 lapon 126 szám alatt. $)^{40}$

2./ 1859-ban elhatározva 1860. június 10-én [Laczkó András szerint 14-én G.F.] a niklai temetőben hatalmas gúla alakú oszlop leleplezése, nagy ünnepség keretében.

3./ A születése centenáriumán 1876. május 6-án Szombathelyen a vármegyeháza nagytermében centenáris ünnepség, másnap Egyházas-Hetyén a szülőházon ünnepélyes emléktábla elhelyezése történt

4./ 1891. október 11. Szombathelyen megalakul a szombathelyi Berzsenyi-szobor bizottság, 1893. május 5-én a Berzsenyi-Kör, 1896. december 8. leleplezik a Berzsenyi-ércszobrot. A fennemlített tényezők elérvén céljaikat: megszűntek. A Berzsenyi kultuszban ezeket követően érdemesebb dolog nem történt." 41

A társaság 1905. március 9-én felolvasómatinét tartott a városházán. Úgy tűnik, volt hatása az érdeklődés hiányán való kesergésnek, mert a tudósító kiemeli, hogy főleg nagyszámú női közönség jelent meg. A szokásoknak megfelelően két programpont volt: először Papp János $A$ vő című egyfelvonásos népszínművét, ezt követően Kohlbach Bertalan Hunyadi Mátyás király a szlovén guzlárdalban ${ }^{42}$ témájú irodalmi dolgozatát olvasta fel. Az előadó beszélt róla, hogy „történelmünk e nagy alakját a délszláv költészet hősei közé iktatta, és most is dalolják, egyre vallják, ki volt Jankó Szibinyáni. Érdekes

40 A történésröl részletesebb adatokkal is rendelkezünk: „A lelkes határozat jó ideig nem öltött testet. 1858-ban Somssich Pál fáradhatatlan buzgalmára újabb mozgalom és gyűjtés indult meg, amely 2000 pengö-forintot eredményezett. A mell-szobor mintázását báró Vay Miklós (1828-1886) díjtalanul vállalta. Bécsben öntötték, 1859 novemberében már elkészült és a múzeum könyvtárában helyezték el. Somssich Pál miután a szobor gránit talapzata is elkészült, felszólította a Múzeumot, hogy a szobrot a Múzeum kertjében állítsa fel, amire 1860. május 29-én került sor." Liber Endre: Budapest szobrai és emléktáblái. A budapesti szobrok és emlékművek története. Budapesti Statisztikai Közlemények 69/1, Budapest Székesföváros Házinyomdája, é.n.

41 A Berzsenyi Társaság 1925-28. évi értesítője. 5. Szerk. Hortobágyi Ágost. Kaposvár, 1929. Merkur Ny.

Hortobágyi Ágost (1875-1931) tanfelügyelö, az 1925-ben újraalakult Berzsenyi Irodalmi és Művészeti Társaság ügyvezető elnöke és krónikása.

42 Kecskebőrrel bevont, hosszú fogantyúval ellátott, egyetlen lószőrhúrral felszerelt, délszláv népi, vonós hangszer, föleg énekmondókat kísérnek vele. A délszláv guszlár dalnokok régi népdalokat, népkölteményeket énekelnek régi dicsőségről - a guszla mellett. 
dalokat ismertetett a délszláv költészet köréböl, amelyek mind Hollós Mátyás királlyal kapcsolatosak." ${ }^{43}$

Május 7-én rendkívüli közgyülésre került sor, amelyen módosították az alapszabályt, ezt követően felolvasó ülést tartottak, amelyen a társaság három rendes tagja Andorka Elek Emlékezés Berzsenyi Dánielről, Hollósi István ( kaposvári népiskolai tanító) Saját költemények és dr. Vass Miklós a főgimnázium tanára Történelmi elbeszélések címmel szerepeltek. ${ }^{44}$

A Somogyvármegyei Berzsenyi irodalmi társaság történetének következő éveiről a továbbiakban már az újonnan létrejött Somogyvármegye című lap tudósításai alapján szólhatunk. Beszámol a szigetvári Vörösmarty-ünnepről, amelyen társaság rendes tagja Pete Márton szónokolt, ezt a lap teljes terjedelmében közöli. Érzékeltetésül csak piciny részletét idézzük:

„Virágom nincs, hogy díszes koszorút helyezzek el ez emlékkő alá, de társaságunk, amely hivatott a hős, a költő dicső, nagy nevét ápolni, ím általam tesz szent ígéretet, hogy ezt a földet, ezt a Kánaánt, ahol a honszeretetnek bő táplálékát aratni lehet, búcsujárásul tartja ezután és hogyha szomjú lelkünk elalél a fáradságos munka naphevén: üdülést szívni ide eljövünk, hol két ily emlék, ím, ölelkezik. És innét hordjuk szét a szent igét, hogy büszke szóval szertehintsük azt: „A nagy világon e' kívül...»"45

A lap augusztustól egy új, folytatásos rovatot indít Regénycsarnok címmel, amelynek elő darabja az Ilka naplója. „A regényt Danka István, városunk jónevü tollforgatója, a Berzsenyi irodalmi társaság tagja írta a mi lapunk számára. Olvasóink előtt nem kell külön kiemelni az írótanár finoman megfigyelő és gondosan kidolgozó írói készségét. Ilka naplója naplójegyzetekben mutatja be egy el szegényedett úrileány sorsát, kit a szükség korán megtanít az önállóságra. Ilka az élet $s$ a szerelem harcát végigküzdve, erős megpróbáltatások után jut el a házasélet csöndes, nyugodt, boldog révébe. A mindvégig változatos meseszövésü és érdekfeszítő regényt jóindulatúlag ajánljuk olvasóink becses figyelmébe." 46

A nyári hónapokat követő első (és mint kiderült egyben az évben utolsó) felolvasó ülésére októberben került sor a városháza dísztermében, amelyet „előkelő és nagyszámú” közönség töltött meg. Végh Endre fögimnáziumi tanár olvasta föl székfoglalóját A virágok szerepe a költészetben címmel. Az irodalmi értekezés „részletesen kitért az összes virágoknak a nép- és müdalokban való alkalmazására, amit sűrű idézetekkel tarkított." 47

43 Felolvasó matiné a városházán. In: Kaposvár, 1905. március 9. p. 3

44 A Somogyvárm. Berzsenyi Irod. Társ. In: Somogy, 1905. május 7. p. 2. A lap a következő számában arról tudósít, hogy a május 7 -én megtartott „dísznagygyűlésen” rendes taggá választották Vikár Bélát, és „Pete Márton ősszel fogja elfoglalni a fötitkári állást.” In: Somogy, 1905. május 14. p. 2. Fel kell figyelnünk rá, hogy a Kaposvár nem tudósított róla.

45 A szigetvári Vörösmarty-ünnep. In: Somogyvármegye, 1905. június 14. p. 3.

46 Hírek Lapunk regénye. In: Somogyvármegye, 1905. augusztus 5. p. 3.

47 A Berzsenyi-társaság ülése. In: Somogyvármegye, 1905. október 17. p. 4
Az 1906-os év nagyszabású eseménnyel kezdődött: Pekár Gyula és Vikár Béla tartotta meg székfoglalóját. „A fölolvasókat, kiket a közönség lelkes éljenzése fogadott belépésükkor, Andorka Elek, a társaság alelnöke üdvözölte. Elsőnek Pékár Gyula olvasott föl, aki »Drághy Éva esküje címmel a Nemzeti-szinházban »Drághy Éva« címen legközelebb színrekerülö drámájának alapjául szolgáló elbeszélését mutatta be. A kellemes érces hangon előadott, finom leírásokban gazdag elbeszélést, amely csak egy a történelmi tárgyú »vitézi románcok« színes sorozatából áll, a hallgatóság szűnni nem akaró tapssal és éljenzéssel jutalmazta. A hoszszabb elbeszélésnek a közlését - a szerző szívességéből - mai számunkban kezdtük el. Ezután Vikár Béla, a magyar népdalok kiváló gyűjtője és tanulmányozója a népköltésröl és különösen a somogyi népköltésről tartott érdekes és vonzó előadást. Vikár Béla népszerű, csevegő modorban előadott értékes előadásában Petőfinek Aranyhoz irt levelét idézi, melyben a nagy költő a népköltészet nagy fontosságát jellemzi, azt állítván, hogy amely nép a költészet terén uralkodik, közel áll ahhoz, hogy a politikában is uralkodjék. Vikár ezután példákkal illusztrálja a magyar népdal föbb tulajdonságait s kimutatja, hogy Petőfi és Arany a népdal alapos ismerete nélkül nem alkothattak volna oly művészien magyaros remekeket. Ezután Somogy megyére térve át, vázolja a somogyi népköltés helyzetét a magyar népköltés keretében. A népdal előadó szerint egész más érzésvilágot tár föl, mint aminő a mi érzésvilágunk. A népet nagy ür választja el a fölsőbb tízezertől és a népdal ismerete azért szükséges, hogy ezt a nagy ürt áthidalja, mert a népdal ismerete kulcs a nép lelkéhez. Vikár célja a közönség érdeklődését fölkölteni a népköltés iránt, mert csak ha ismerjük a népet, úgy tudjuk azt meghódítani a mi eszménknek. [...] Este a Korona étkezőjében szükebb körü társasvacsora volt, amelyen számos pohárköszöntő hangzott el."48

A lelkes olvasó ekkor még nem sejthette, hogy ez a tudósítás volt az utolsó a társaság életében, amikor még elismerő szavakkal jutalmazták. Júniustól minden megváltozott, és a sajtó hozzáállása is egyre keményebb lett. A kezdetet egy rendezvénytől való távolmaradásra való reagálás jelentette: „A minap volt Budapesten a múzeumok és könyvtárak országos szövetségének a gyűlése. Ott megjelentek az összes vidéki múzeumok, irodalmi társaságok és közkönyvtárak képviselői. Jelen volt a nyíregyházai Bessenyei irodalmi kör, amely pár hónap előtt alakult meg, az elnök és a titkár által képviselve. Csak a kaposvári Berzsenyi irodalmi társaság hiányzott. S aztán miért? (Nem hisszük, hogy a Berzsenyi társaságot ne hívták volna meg erre a gyűlésre, ha a sokkal ifjabb nyíregyházai testvértársaságot meghívták.) Mert hát a Berzsenyi társaság alszik. Nem is fárasztjuk magunkat azzal, hogy megkérdezzük, mit tett immár kétéves fönnállása óta az irodalom s ezzel együtt a közművelődés terjesztése érdekében. Hiábavaló munka volna. Hisz a társaság

48 Irodalmi ünnepség. In: Somogyvármegye, 1906. február 18, p. 6. 
még a havonkénti fölolvasó üléseket is, amiket pedig az alapszabály előír, elmulasztja - csupa feledékenységből. Legjobb volna tehát, ha a Berzsenyi-társaság, ha már úgy sincs, hivatalosan is bejelentené megszünését. Talán fog indulni egy egészségesebb, életrevalóbb, erővel teljesebb mozgalom, amely nem fog önmagába fülni. Mi nem hagyjuk elaludni az eszmét és napirenden tartjuk azt tölünk telhető igyekezettel. Mert most eljött minden célszerü és hasznos, egész emberéletre kiható erejü intézménynek a megvalósítására a legalkalmasabb időpont. Új korszak, az alkotmányos, a nemzeti kormányzás hajnala köszöntött reánk, amit mindenki oly epedve várt hosszú idők óta." ${ }^{49}$

Közel nyolc hónapnak kellett eltelnie ahhoz, hogy ismét halljunk a Berzsenyi irodalmi társaságról. Nem sok örömünk telik benne.

„A mi kies szép hazánkban egyre alakulnak az irodalmi körök, anélkül azonban, hogy az irodalom terén bármit is lendítenének. Városunknak is van egy irodalmi társasága, a Berzsenyi-társaság, de annyit se tesz a közönség irodalmi szükségleteinek kielégítésére, mint egy krajcáros bulvárlap. A társaságnak egy esztendő óta nem volt ülése. Sőt életjelt sem ad magáról, mintha csak meghalt volna. Valószínűleg ez lesz a hosszú haldoklásnak a vége, mert nemsokára az alapszabályok értelmében a társaság úgyis megszűnik. Ilyen irodalmi kör alakult nemrégen a fővárosban a lángeszü Vajda János nevével. A kör elnöke Koroda Pál és városunkban is van egy számottevő tagja, Szalay Fruzina. Nem tudjuk, mit tett az új irodalmi-kör az irodalom érdekében, de ha csak azt tüzte is ki célul, hogy a feledésbe menő Vajda János költői érdemét kellőképen méltatja, és az őt megillető helyre állítsa, akkor is megérdemli támogatásunkat."50

Nehéz megítélni, hogy valóban a Vajda János kör támogatására íródott-e az újságcikk, vagy valódi oka az elmarasztalás lehetőségének kihasználása volt. A hivatkozott kör ugyanis nem született meg, az csak 1926-ban alakult Vajda János Irodalmi Társaság néven, ami miatt Koroda Pál elnöki tevékenységéről sincsenek (lehetnek) forrásaink.

Nem tudni, milyen érzelmeket válthatott ki a Somogyvármegye 1907. március 10-ei száma a Berzsenyi társaság minden rendü és rangú tagjából, az irodalom iránt érdeklődő olvasóból, amikor a következő, meghökkentő újságcikk került a szeme elé.

„Az ország minden nagyobb városában van valami irodalmi vagy kultúregyesület, amely nevét valamelyik költőnktől vagy írónktól vette. De ezek az irodalmi társaságok többnyire méltatlanok ahhoz, akinek a nevét viselik, aminek az a sürün fölhangzó, általános panasz és vád az eredménye, hogy a vidéki irodalmi körök nem felelnek meg a tulajdonképpeni hivatásuknak. Azonban talán egy vidéki irodalmi egyesület ellen sem oly jogos a panasz, mint éppen a Berzsenyi-társaság ellen. Pedig milyen szép reményekkel állták körül e

49 Múzeum Kaposváron. In: Somogyvármegye, 1906. június 17. p. $1-2$.

50 Egy irodalom-kör kérelme. In: Somogyvármegye, 1907. február 10. p. 4-5. csecsemő korát élő irodalmi körnek a bölcsőjét, mikor ezelőtt mintegy három esztendővel megszületett. Az ünnepi keresztelőnél maga Rákosi Jenő, az újságírás atyamestere is jelen volt. S a jókívánságok közül, amikkel a fejlődésre hivatott csemetéjét, vajon mi valósult meg? - Bizony semmi, de semmi...

Mostanában a vidéki sajtó sürün foglalkozik a helyi irodalmi körökkel és valóban szigorú bírálója azok müködésének. A bírálat végeredményében aztán arra a következtetésre jut, hogy legjobb lesz, ha megszünik, mert úgysem felel meg kitűzött céljának és nem termel semmit. Pedig a nyíregyházai Bessenyei kör minden hónapban országos hírű irodalmi és múvészi zsúrokat rendez. Debrecenben a Csokonai-kör pályaíjakat tűz ki és fiatal, kezdő írók és poéták könyveit kiadja. Ez a kör adta ki az oly hirtelen nevessé vált Farkas Imre első könyvét is. A nagyváradi Szigligeti társaság minden hónapban többnyire fővárosi irodalmi körök közremüködésével irodalmi matinékat tart. Képkiállítást rendez a Nemzeti Szalonnal vagy a mücsarnokkal. Azonkívül kirándul fölolvasásra a közeli román vidékekre, ahol nemzeti és kulturális missziót teljesít. Aradon a Kölcsey-egyesület nemrég színdarabra hirdetett pályázatot, mégpedig szép sikerrel. Temesváron az Arany János-társaságnak járt le nemrég több irodalmi pályázata és már kitüzték az újakat. Ezek az irodalmi körök mind tudnak valamelyes eredményt fölmutatni és a közönség, a nyilvánosság és a sajtó még sincs megelégedve a működésükkel. Néhány nap előtt az aradi Kölcseyegyesületben éppen a színmüpályázat kapcsán merültek föl a legkomolyabb hangok, hogy az egyesületet föl kell oszlatni, mert senki sem veszi komolyan a tagok közül a maga kötelességét és mert a bíráló bizottság nem készült el véleményével a színdarabokról. Sőt a szomszédos Zalaegerszegen és Nagykanizsán is nagyobb fokú irodalmi élet van, mint nálunk. Csak a kaposvári Berzsenyi irodalmi társaság nem ad magáról életjelt. Kaposvár város közönsége jóformán azt sem tudja, hogy van Berzsenyi-társaság is a világon. Mert honnan tudná, ha nem a társaság müködéséből. A müködés hiánya pedig nem jelentheti a társaság létét. Már két év óta nem tartott a Berzsenyi-társaság évi rendes közgyülést, amit az alapszabályok 15. pontja minden év januárjára ír elő. Hogyan akar egyáltalán megfelelni kitűzött céljának, amelyet az alapszabályok 2. pontja a következőkben körvonalaz: A szépirodalom művelése és terjesztése, a Somogy megyei népköltés gyöngyeinek gyűjtése és megőrzése, bizalmas közeledés létrehozása az irodalom munkásai és a közönség közt. Mi módon lehetne vajon ezt a közeledést létrehozni, ha nincs meg annak egyik fontos eszköze, a fölolvasás. Hisz a legutóbbi fölolvasó ülés egy év előtt volt. Holott az alapszabályok 14. pontja megszabja, hogy - június, július, augusztus és szeptember hónapok kivételével minden hónap első vasárnapján kell fölolvasó ülést tartani. Sőt még az ünnepi nagygyűlést sem tartották meg, amit az alapszabály 16. pontja Berzsenyi Dániel születésnapját, május 7-ét követő első vasárnapra ír elő. Arról nem is szólunk, hogy a célok elérésére szolgáló és az alapszabályokban kifejezett irodalmi termékek és 
évkönyv kiadása, pályadíjak kitüzése, a társaság saját közlönye útján a közönség irodalmi tájékoztatása és a színházi előadások irányítása tekintetében semmit sem valósított meg. A legutóbbi, az egy év előtti fölolvasással, amelyen Pekár Gyula és Vikár Béla müködtek közre, megpróbálták ezt a vértelenségben senyvedő egyesületet föléleszteni, de a kísérlettel járó fáradság kárba veszett. S vajon kit okozzunk ezért a pangásért és tehetetlenségért? A közönséget nem lehet, mert hiszen éppen a közönség részvétlenségének legyőzésére alakult a társaság. De meg a közönség bebizonyította, hogy fogékonysággal bír az irodalom iránt, mert Pékár fölolvasásán zsúfolásig megtelt a városháza díszterme, sőt még a sokkal kevésbé érdekes fölolvasáson is nagyszámú hallgatóság jelent meg. Csak a társaságot, különösen pedig a vezetőséget okolhatjuk a Berzsenyitársaság tehetetlenségéért és ennek folytán Kaposvár irodalmi életének pangásáért. A társaság vezetését erélyesebb, odaadóbb, lelkesebb és buzgóbb kezekbe kellett volna letenni. Ezt maguk a dolgozni akaró tagok is belátták, akik - így a társulat titkára is - kiváltak és lemondtak. A Berzsenyi-társaság tehát, mint irodalmi tényező, már régóta nem létezik. Szűnjék meg akkor jogilag is és a lekötött tőkét adják át az alapszabályokban előirt rendeltetésének valami hasznosabb és gyümölcsözőbb célra. Össze kell végre hívni a társaság közgyülését és azon vagy tegyenek egy utolsó kísérletet a Berzsenyi-társaság föltámasztására, vagy pedig mondják ki a föloszlást, mert ez a tehetetlenség és terméketlenség nem méltó sem Berzsenyihez, sem ahhoz az irodalmi társasághoz, amely az ő nevét viseli." ${ }^{\text {1 }}$

Azt gondolhatnánk, hogy ezek után már felgyorsul a Berzsenyi irodalmi társaság reagálása, és megkísérli a folyamat lassítását elérni, a közhangulat romlását megakadályozni. Nem így történt. Május végéig nem történt semmi említésre méltó esemény a társaság életében, csak ekkor ült össze ismét a választmány, a vármegyeháza nagytermében, Andorka Elek elnöklésével. Az ülésen a választmányi tagok meglehetősen csekély számban jelenlek meg, mindössze öten voltak. A tudósításban olvassuk: „Nem tudjuk megérteni ezt a részvétlenséget, amellyel a tagok ez iránt a szép reményekkel megindult társaság iránt viseltetnek. Ez a részvétlenség volt eddig is a társaság megölője, amit végre a vezetők is beláttak. Ugyanis a tegnapi ülésen sajnálattal állapították meg, hogy a húsz rendes tag közül kilencet nem tudták rábírni, hogy székfoglalóját megtartsa. Ez volt az oka annak, hogy a társaság nem tudott fölolvasó üléseket tartani, mert nem lehetett mindig vendégeket kapni. A választmány a társaságot megmentendő, elhatározta, hogy szeptemberben összehívja a közgyűlést. A közgyülésen az egész tisztikar le fog mondani és fölhívja a tagokat, hogy a részvétlenség tovább terjedésének meggátlása végett teljesen szervezze újra a társaságot." 52

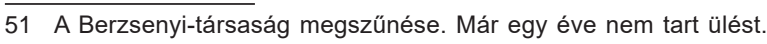
Elpusztul a tehetetlenségtől. In: Somogyvármegye, 1907. március $10 .$, p. $2-3$

52 A Berzsenyi-társaság ülése. In: Somogyvármegye, 1907. május 25. p. 4
Júniusban megszólal a Berzsenyi irodalmi társaság agg elnöke, akit fia halála és betegsége akadályozott abban, hogy részt vegyen, vagy befolyásolja a történéseket. Levelet ír a szerkesztőnek, amelyet a lap leközöl:

„A Somogyvármegyei Berzsenyi irodalmi társaság elnöki állásáról, mellyel megtiszteltek, még a múlt őszszel leköszöntem nagy gyászom [elvesztete fiát G.F.] és gyöngélkedésem miatt, nehogy a társaságot munkálkodása és fejlődésében gátoljam. Ez idő óta a társaság működéséről nem hallottam, csak a napokban, midőn hosszú távoliét után hazatértem, vettem a hírt, miképp közelebb összejövetele volt s azt határozták, hogy az ősz mentén összehívják a közgyűlést a teendők megbeszélése végett. Igen helyesen!

Nem tudom ugyan, mi lesz a határozat; egyet azonban érzek, tudok: hogy az irodalmi társaságnak fönt kell állnia, s ha nem volna, meg kellene alapítani, hogy legyen, virágozzék és fönnálljon hosszú időkön át.

Miért? Mert nemcsak az irodalmat szolgálja, mely hazafiul kötelesség, de a közművelődésnek előmozdítója, mely nem stagnálhat az ország egyik első megyéjében, mert az ország számos vidékén sikerrel müködnek az irodalmi társaságok; egyetlen egy meg nem bukott, sőt a budapesti központtal egyetértve, nagy célok után hevülve, a nemzeti érdekek szolgálatába állva, aratják a legszebb sikereket. Mert a közönséget, melynek a megalakulást bejelentettük, szolgálatunkat érdekeiért odaígértük, s ily értelemben támogatását kértük, nagy okok és akadályok nélkül, hallgatva ott hagyni nem lehet. Mert a társaság fölhívására a céljai iránt lelkesedő egyének szép összegü alapítványt tettek le, mely takarékpénztárban kezeltetik, s ezt az ígért program kiváltásával, folytonos buzgó müködések sikerével kell kiérdemelni. Aztán az Istenért! Berzsenyi, a nagy óda-költő nevét viseli a társaság, ez a szív pedig halhatatlan; »nem fél az idők mohától, kitör a koporsóból és eget kér«! Mert mint Rákosi Jenő, a nagy gondolkodó, a megnyitó közgyülésen szép beszédében elmondta, amit én is a megnyitó beszédemben hangsúlyoztam: itt van a határunknál a Dráva, honnét folytonosan zivataros és hideg szél csap át, tehát erősségeinket nemcsak rendben, teljes erőben kell tartani, de újakat és újakat építeni, hogy itt az ország határszélén a mindig magyar, a mindig vitéz, annyi véres harcban dicsőséget küzdő Somogyvármegye bármely időponton megtehesse kötelességét, ha békeszeretetünk dacára is veszély fenyegetne békénket $\mathrm{s}$ a haza híná hű fiait. Legelső sorban azért kell fönt állnia az irodalmi társaságnak; művelni, lélekben erősíteni és lelkesíteni! A toll katonái sokszor fényesebb győzelmeket aratnak, mint a véres harcok küzdő vitézei. [...] Tehát minden akadályt le kell győzni. A poklokon is diadalmaskodni, hogy az irodalmi társaságot megmentsék. Ha az alapszabályokban van baj, meg kell változtatni. Ha a közöny hideg kezével érintené e fiatal hajtását a nemzet fájának, hallgatása s föl nem mutatható sikerek miatt, - le kell győzni; új erőt gyüjteni; a lelkesedés már nagyobb csudákat is tett! Lehet remélni; lehet küzdeni; a zászlót magasabbra emelni; de - meghalni nem! Roboz István."53

53 A Berzsenyi-társaság hanyatlása. Roboz István leköszönése. Meg kell menteni a társaságot. In: Somogyvármegye, 1907. június 9. p. 2. 
Logikusan gondolhatnánk, hogy Roboz levelének következményei lesznek, ám szavainak nem volt hatása. Megmagyarázhatatlan, hogy mi történt a korábban oly nagy lelkesedéssel és szép reményekkel létrejött Berzsenyi irodalmi társasággal és különösen az azt alkotó személyekkel. Az agg elnök ereje fogytán volt, neki már csak a tekintély lehetett fegyvere, amely - mint tudjuk az idő múltával veszít hatékonyságából. Az alapításkori tisztségviselők még élnek, bár némelyikük magánéleti válsága (Endrei Ákost a Berzsenyi szabadkőműves-páholy alapító tagját és Pete Mártont törlik a páholy tagjai sorából, Kohlbach Sebestyén csalódottan és sértetten elhagyja a várost), úgy tünik, sietteti a vég bekövetkeztét. A korabeli helyzetértékelés szerint „a pártoló tagjai elmaradoztak, a működő tagok érzéktelenné váltak, nem törödtek a kör dolgaival; 1906. október havában pedig maga az elnök, Roboz István is lemondott eme tisztségéről. Azaz, hogy csak lemondott volna, ha lett volna kinek, ha lett volna, aki e lemondást tudomásul vegye. 1906 októbere óta nem tudott az elnökség egy ülést öszszehívni, helyesebben: összehozni, mely a Roboz István lemondását tudomásul vette volna és a továbbiakban határozott volna. Azóta van is, nincs is a Berzsenyi kör. Van, mert hivatalosan föl nem oszlott, meg nem szünt és mert adósságai egyre szaporodtak; de viszont [sic!] nincs, mert maga az elnökség is ott hagyta.

Egyetlen egy ember sem tudja a kör tagjai, vezetői közül, hogy mi van a kör vagyonával, mi van azokkal a könyvekkel melyeket a nemzeti szövetség küldött évek során a körnek és amelyeknek áráért most pörölni fogja a kört; nem tudjuk van-e pénztáros, nincs-e pénztáros, lemondott-e nem-e; ki kezeli a kör pénzét, vagy van-e még egyáltalán valami pénze a körnek? Egy bizonyos, hogy a Berzsenyi-kör teljesen belefulladt a zavarosba. Ezt tudják ma már azon kevesek is, akik kényszerből, mert esetleg anyagilag is érdekeltek lehetnek, - nagy ritkán még gondolnak itt-ott a körre. Ezek most gyülést akarnak összehívni, melyen kimondják a Somogymegyei Berzsenyi irodalmi kör végleges föloszlását, és elhatározták, hogy a kör esetleg - létező vagyonának fölszámolását vagy a Somogyvármegyei Közművelődési Egyesületbe, vagy pedig a Somogymegyei Múzeum Egyesületbe beleolvasszák."54

Az újságcikkre Pete Márton válaszolt: „Igen tisztelt szerkesztőség! Vasárnapi számukban a Somogy-vármegyei Berzsenyi irodalmi társaságról megjelent közleményükre vonatkozólag úgy a tisztelt szerkesztőség, mint a nagyközönség tájékoztatására kötelességem szerint közlöm, hogy a társaság ügyeinek végleges rendbehozásán igenis dolgozunk s alig várjuk, hogy határozatképes közgyűlést hívhassunk egybe, ahol minden tekintetben a társaság állapotáról beszámolhassunk. Tény, hogy a részvétlenség a társaságot válság elé vitte; épp azért a legmegfelelőbb kibontakozást keressük. Ebben a munkánkban azonban tán joggal számíthatunk a sajtó támogatására; éppen azért

$54 \mathrm{Hol}$ van a Berzsenyi-kör vagyona? Még az elnök sem tudja. Egy irodalmi kör csődje. Beolvad a múzeum-egyesületbe. Pör az el nem számolt pénzek miatt. In: Somogyvármegye, 1909. március 14. p. $2-3$. kérjük, hogy addig míg közgyülésünk eredményét nem közölhetjük: a vezetőség iránt való bizalommal méltóztassék ezt az ügyet is kezelni. Kiváló tisztelettel Pete Márton dr. főtitkár." 55

Április 4-ére dr. Andorka Elek tiszti föügyész választmányi és rendkívüli közgyűlést hívott össze a városháza nagytermébe, a kör föloszlása ügyében, amelyen mindössze négyen jelentek személyesen, többen levélben jelentették be, hogy a kör föloszlatásához hozzájárulnak. Az elnök bejelentette, hogy Pete Márton, a kör titkára betegségére hivatkozva levélben kért néhány napi haladékot az elszámolások bemutatására. A megjelentek ehhez hozzájárultak, így majd csak az elszámolások bemutatása után mondhatja ki a Berzsenyi-kör végleges föloszlását, pontosabban fogalmazva beleolvadását a Somogymegyei Közművelödési Egyesületbe. Ezzel egyúttal elfogadták, hogy a társaság „több száz korona" vagyonát az Alapszabály értelmében a Közmüvelődési Egyesületnek fogják átadni. ${ }^{56}$

A vagyonátadást a Közművelődési Egyesület június 19-i közgyűlésén Kacskovics Lajos alispán elnöklése mellett a vármegyeház kistermében tervezték elvégezni. Ismét csak néhány tag jelent meg. Andorka Elek dr. beterjesztette a számvizsgáló bizottság jelentését, amely a Közművelődési Egyesület pénztári számadásait rendben találta. Ezzel együtt meg kellett állapítani, hogy a föloszlott Berzsenyi irodalmi társaságnak a Közművelődési Egyesületre átruházott vagyona hiányzik, mert a társaság pénztárosa még mindig nem fizette be azt az egyesület pénztárába. ${ }^{57}$

A bizonytalanság nem oszlik, a kérdések és kételyek szaporodnak. A Somogyvármegye rendszeresen visszatér az ügyre, de úgy tünik eredménytelenül: „Kénytelenek vagyunk azt hinni, hogy valami baj történt a Berzsenyi-társaság vagyonával, hogy az elszámolás - dacára a többszöri ígéreteknek - ily nehezen születik meg. Most újból kérdezzük, hol a föloszlás előtt álló irodalmi társaság vagyona és miért nem történt meg ma az elszámolás? Távol áll tőlünk minden gyanúsítás, de szinte föltűnő, hogy miért e sok huzavona az elszámolás körül. Mi úgy tudjuk, hogy a Berzsenyi társaság vagyona készpénzben volt meg és azt egyik helybeli takarékpénztárban kezelték. A leszámolásnak tehát semmi különösebb akadályai sem lehetnek, ha ezt tényleg végre akarják hajtani. A Közmüvelődési Egyesületnek ma már nemcsak joga, de egyúttal kötelessége is azt követelni, hogy ez a leszámolás végre megtörténjék és ez annál könnyebb, mert hisz egy kis takarékbetét- könyvecske egyszerủ átadásáról van csak szó, ami különösebb akadályokkal alig járhat. Ha pedig mégis vannak akadályai az elszámolásnak, úgy elvárjuk a közművelődési egyesülettől, hogy ezt nyilvánosságra hozza." 58

55 A Berzsenyi-kör csődje. In: Somogyvármegye, 1909. március 16. p. 4.

56 A Berzsenyi kor föloszlása. In: Somogyvármegye, 1909. április 6. p. 4.

57 Hol a Berzsenyi-társaság vagyona? In: Somogyvármegye, 1909. június 20. p. 6.

$58 \mathrm{Hol}$ a Berzsenyi-társaság vagyona? Miért késik a leszámolás? Már hónapok óta ígérik. De egyre húzzák-halasztják. In: Somogyvármegye, 1909. július 4. p. 3-4. 
„A többi néma csend” - idézhetnénk a nagy tragédia ide illő mondatát. ${ }^{59}$ Csak bő három évvel később értesülünk új kezdet, vagy folytatás lehetőségéről, hogy aztán ezt is elmossa a valóság.

„Kaposváron és Somogymegye egész területén már régen érzik egy irodalmi és múvészeti egyesülésnek hiányát. $A$ »Somogyvármegye« ez ügyben már többször föl is emelte szavát és a nagy nyilvánosság előtt mutattunk rá egy ilyen egyesülés szükségességére. Szavunk nem maradt a pusztában elhangzott szó. Az illetékes körök érveink alapján szintén magukévá tették az eszmét és így az irodalmi és művészeti kör ügye ma már olyan stádiumban van, hogy azt ez év végén meg is fogják alakítani. A mozgalom élén Somssich Géza áll, aki legközelebb már meg is fogja tenni a megalakítást megelőző munkálatokat."60
A remélt legközelebbre 1925-ig kellet várni, amikor valóban feléledt - immár új névvel - mint Berzsenyi Irodalmi és Művészeti Társaság. ${ }^{61} \mathrm{~A}$ történetét bemutató nagyszámú, különböző indíttatású tanulmányok, közlemények ezekről a viszontagságos évekről vagy nem tudnak, vagy szemérmesen hallgatnak. Ezzel együtt a sajnálatos ürt betölteni hivatott azon állításokat, miszerint, idézem: „a társaság működésének eredményeként a megalakulást követően röviddel már olyan neveket olvashatunk a Kaposváron szereplő művészek között, mint Adyé, Reinitzé, Medgyessyé" törölni lehetne. Az igazság (a valóság) ismerete (bevallása) nem csökkenti az elődök érdemeit.

Irodalomtörténészeknek kell eldönteni, hogy az újrakezdés új fogantatást jelentett-e, vagy csodás feltámadást. ${ }^{62}$

\section{Irodalom}

BERZSENYI DÁNIEL LeVElezÉse 2014: (Kiad. Fórizs Gergely, a latin szövegeket ford. Balogh Piroska), Budapest

CSÁNKI D. (Szerk.): Magyarország vármegyéi és városai Somogy vármegye. Országos Monográfiai Társaság Budapest, é.n.

Gáspár F. 2012: A kaposvári „Berzsenyi” Szabadkőműves páholy. Kaposvár.

HEgEdüs G. 1976: Irodalmi arcképcsarnok A magyar irodalom arcképcsarnoka. Budapest.

HETYEY J. 1936: Kaposvár, mint kultúrközpont. Berzsenyi Társaság propaganda kiadása, Kaposvár.

HoRTOBÁGYI Á. 1929: (szerk.): A Berzsenyi Társaság 1925-28 évi értesítője. Kaposvár

KAPosvÁR (alcím nélkül): XIX. és XX. évfolyam (1904-1905)

LACKÓ A. 1993: Múzsák a Kapos partján. Kaposvár.

PINTÉR J. 1934: Magyar Irodalomtörténet A magyar irodalom a XIX. század utolsó harmadában. Budapest.
Sherwood, P. 2019: Adalékok a Nyelvében él a nemzet szállóige kialakulásához. Szó és szólásmagyarázatok. Magyar nyelv, 2019. tavasz.

DR. Sipos Cs. 2004: A Berzsenyi Társaság centenáriuma. Somogyi Honismeret, 1. szám

SOMOgY POLITIKAI ÉS VEgYES TARTALMÚ HETILAP: 41. és 42. évfolyam (1904-1905)

SOMOGYI HíRLAP Független napilap I. évfolyam (1904)

SOMOGYI UJSÁG Megyei és helyi érdekű vegyes tartalmú hetilap XI. évfolyam (1904)

SOMOGYVÁRMEGYE Politikai napilap 1905-1912. évfolyam

SZATHMÁRY-KIRÁLY Á. 2014: A szabadkőmüves Kazinczy. Magyar Múzeumok a Pulszky Társaság Magyar-Múzeumi Egyesület Online magazinja, 2014. 02. 25

VARGA I. 2004: A Berzsenyi Társaság története. Somogy, 5. szám.
59 Shakespeare: Hamlet.

60 Irodalmi és mủvészeti kör Kaposváron. In: Somogyvármegye, 1912. október 5. p. 5
61 A MNL SML-ban őrzött, 1904. augusztus 18-án jóváhagyott A „Somogyvármegyei Berzsenyi irodalmi társaság” Alapszabályai utolsó lapjának hátoldalára ceruzával írott feljegyzés szerint: „Ujjáalakult 1925. évi szept. 24. Ujjáalakulás utáni címe: „Berzsenyi Dániel Irodalmi és Művészeti Társaság”. Jóváhagyási száma: 270661/1926 VII.".

62 A Berzsenyi irodalmi társaság első felolvasására 1904. októberében, az utolsóra 1906. februárjában került sor, ami az Alapszabályban megfogalmazott célnak megfelelő, közel másfél évnyi aktív működést jelent. A további, a feloszlásig terjedő időszakot már kóma állapotnak minősíthetnénk. 


\section{Függelék}

\section{A „Somogyvármegyei Berzsenyi irodalmi társaság” Alapszabályai}

\section{$1 . \S$.}

A társaság címe, pecsétje és székhelye. A társaság címe: „Somogyvármegyei Berzsenyi irodalmi társaság".

Pecsétje: Somogyvármegye címere körül a következő szavak: „Somogyvármegyei Berzsenyi irodalmi társaság 1904.- Székhelye: Kaposvár

\section{2.§.}

\section{A társaság célja:}

A társaság célja Berzsenyi Dániel és Somogyvármegye más jelesei emlékének ápolása; a magyar szépirodalom, szépműtan, a tudomány művelése és terjesztése; a somogyvármegyei népköltés gyöngyeinek gyűjtése és a népélet összes megnyilvánulásainak megőrzése az utókor számára; bizalmas közeledést hozni létre az irodalom munkásai és a szellemi munkát megbecsülni tudó közönség között.

\section{3.§.}

A cél eszközei.

Szépirodalmi, tudományos és szépműtani tárgyú felolvasások, irodalmi ünnepélyek rendezése: jelesebb irodalmi termékek és évkönyv kiadása; pályadíjak kitüzése; irodalmi tájékoztatása a közönségnek a helyi lapok, esetleg a társaság saját közlönye útján: Ugyanezen az úton való irányítása a színházi előadásoknak.

\section{4.§.}

A társaság tagul belép az Országos irodalmi szövetségbe s egy rendes tagját küldi a szövetség választmányába.

\section{5.§.}

\section{A társaság tagjai.}

A társaság tagjai: tiszteletbeliek, alapítók, rendesek és pártolók.

$$
6 . \S .
$$

A tiszteletbeli tagok.

Tiszteletbeli tagok, akiket a társaság két rendes tag megokolt írásbeli ajánlatára kiválóbb irodalmi érdemeik alapján életük fogytáig a jelenlévő rendes tagok kétharmad szótöbbségével megválaszt.

\section{7.§.}

Az alapító tagok.

Alapítótagok, kikatársaság céljairaegyszersmindenkorra legalább 200 /kettőszáz/ koronát a társaság pénztárába befizetnek.

8.§.

A rendes tagok.

Rendes tagok azok a Somogyvármegyében lakó feddhetetlen jellemű egyének, akik a társág célját szellemi közreműködésükkel mozdítják elő. Rendes tag lehet összesen tíz oly nem somogyvármegyei lakos is, kik e társaság célját, érdekeit ugyancsak személyes közreműködéssel előmozdítják. - A rendes tagok száma ötven: választásuk egy rendes tag írásbeli indokolt ajánlatára a rendes tagok általi titkos szavazás útján abszolút szótöbbséggel történik. - A rendes tagok ezen tagsági minőségüknél fogva tagjai az „Országos irodalmi szövetség"-nek Budapesten.

9.§.

A pártoló tagok.

Pártoló tagok azok, akik évente hat korona pártoló tagsági díjat fizetnek. A belépés három egymás után következő évre köteles és ezen idő elteltével is, hacsak a kilépés előre $1 / 4$ évvel a fötitkárnál be nem jelentetett. Belépés napjául a belépés első napja számít.

10.§.

A tagok jogai.

A társaság tiszteletbeli - alapító - és rendes tagjai, - ez utóbbiak székfoglalójuk alkalmával, a tagság minőségének megjelölésével oklevelet kapnak és jogosultak a „Somogyvármegyei Berzsenyi irodalmi társaság /tiszteletbeli - alapító - vagy rendes/ tagja” címet viselni. Ugyanezek részt vehetnek a társaság tanácskozásain, ülésein és előadásokat, felolvasásokat tarthatnak. Előadást és felolvasást tarthatnak a meghívott vendégek is. A pártoló tagok s a meg nem hívott vendégek felolvasásra szánt dolgozatai a rendes tagok előzetes bírálata alá esnek s csak rendes tag által olvashatók fel.

Az alapító és pártoló tagok ingyen kapják az „Országos irodalmi szövetség” évi kiadványait és a társaság évkönyvét. A tiszteletbeli és rendes tagok az évkönyvet ingyen, a pártoló tagok 4 korona lefizetése ellenében kapják a társaság főtitkári hivatala útján.

A pártoló tagok ingyen vehetnek részt a társaság felolvasó ülésein és ünnepélyein, kivéve a külön belépti díj mellett rendezendő nagyobb szabású ünnepségeket.

11.§.

A tagok kötelezettségei.

A pártoló tagok kötelesek a tagsági díjat negyedéves előleges részletekben megfizetni. Hátralékok behajtására a Kaposvárott székelő sommás bíróság illetékes. A rendes tagok tartoznak székfoglalójukat egy év alatt megtartani, s az üléseken, ünnepélyeken tartott felolvasásaikat a társaság évkönyve, esetleg közlönye-, számára oly feltételek mellett átengedni, aminő mellett azokat a társaság - mindig vállalt akkori állásához képest - átveheti. E munkák különben az író tulajdonát képezik.

12.§.

A társaság kormányzata.

A társaság ügyeit a választott tisztviselők és a rendes tagok vezetik.

A tisztviselőket a rendes tagok titkos szavazással választják. 
Választásuk a rendes évi közgyűlés napján történik és három évre szól, amely idő elteltével azonban újra választhatók.

Ha választásnál általános szótöbbséget egyik jelölt sem kapna, a második szavazás a legtöbb szavazatot nyert két egyén között történik.

A társaság tisztviselői:
a/ a díszelnök,
b/ az elnök
c/ két alelnök
d/a fötitkár
e/ a titkár
f/ a pénztáros
g/ ellenőr
h/ az ügyész

Az elnök és az alelnökök, a fötitkár, a titkár és ellenőr csak a rendes tagok sorából választhatók. Pénztáros és ügyész pártoló - sőt nem tag is lehet; ez esetben azonban csak a hatáskörüket illető ügyekben, s csak indítványozási és tanácskozási joggal bírnak.

A háromévenkénti tisztújító ülésen a tagságra és a korra nézve legidősebb tag elnököl. Időközi választásoknál a rendes ülési formák alkalmazandók s az ily választás csak a három évi ciklus még hátralévő idejére szól.

$$
\text { 13.§. }
$$

A társaság vagyona.

A társaság vagyonát a tagsági díjakból, az alapítványokból, a kiadványokból és a belépő díj fizetése mellett rendezett ünnepségekből befolyó jövedelmek, továbbá az esetleges adományok, hagyományok s más bevételek képezik.

Feloszlás esetén avagyon elsősorban Somogyvármegye valamely hasonló célú társaságának, ilyenek nem lévén az „Országos irodalmi szövetség”-nek jut, ott mint "Somogyvármegyei Berzsenyi alapítvány” kezelendő.

\section{4.§.}

A társaság rendes üléseit, - június, július, augusztus és szeptember hónapok kivételével, - minden hónap első vasárnapján tartja.

Ezeknek az üléseknek tárgyai: a társaság működési körébe illő felolvasások, vitatkozások, szónoklatok és előadások.

Az ülések nyilvánosak; de a rendes tagok - akár a felolvasó ülések végén, akár külön e célra meghatározott időben - évenként legalább négyszer zárt ülést tartanak a folyó ügyek elintézése végett. lly zárt ülés hat rendes tag részvételével határozatképes; határozatai a közgyüléshez fellebbezhetők. A zárt ülések külön bizottságokat küldhetnek ki.

A társaság a megye, - különös esetekben a Dunántúl - városaiban is tarthat ülést, működési körébe illó felolvasások előadások, ünnepségek rendezésével.

\section{5.§.}

\section{A közgyülés}

A társaság minden év január havában Kaposvárott közgyűlést tart, melyen a tiszteletbeli, alapító és rendes tagok tanácskozási és szavazati joggal, amíg a pártoló tagok csak tanácskozási joggal bírnak.

A közgyülés tárgyai:

$1 /$ a fötitkári jelentés

2/ a pénztáros jelentése és az évi zárószámadás beterjesztése

3/ a számvizsgálók jelentése

4/ költségvetés

5/ /:esetleges:/ a tisztviselők díjainak megállapítása

6/ indítványok tárgyalása. Indítványokat az elnökségnek legalább nyolc nappal a közgyűlés napja előtt írásban kell benyújtani.

7/ jegyzőkönyv hitelesítők kiküldése

Rendkívüli közgyűlést a felmerülő szükséghez képest az elnök /vagy helyettese/, bármikor hívhat össze; tíz rendes tag írásbeli kívánságára pedig összehívni tartozik.

A közgyűlés idejéről és helyéről a tagok kellő időben kibocsátott s a tárgyak felsorolását tartalmazó meghívók útján értesítendők.

16.§.

A nagygyűlés

A társaság minden évben Berzsenyi Dániel születése napját, május hó 7-ét követő első vasár/-ünnep -/napon egy rendes ünnepélyes nagygyűlést tart. Ennek tárgyát szépirodalmi, szépmütani, tudományos felolvasások, szónoklatok, előadások képezik; ezen tesz jelentést a főtitkár a társaság szellemi működéséröl, ekkor hirdettetnek ki a pályázatok és osztatnak ki a pályadíjak. A nagygyűlésen lehetöleg a díszelnök elnököl.

\section{7.§.}

Az elnökség

A társaságot hatóságok és harmadik személy irányában az elnök képviseli. Elnököl a közgyülésen és üléseken, esetleg a nagygyűlésen is. Utalványozza a társaság által jóváhagyott fizetéseket. Szükség esetén utólagos jóváhagyás és felelősség mellett 200 /kettőszáz/ koronáig előirányzat nélkül is utalványozhat.

Az elnököt az alelnökök valamelyike helyettesíti.

\section{8.§}

A főtitkár

A főtitkár viszi a társaság levelezéseit, szerkeszti az évkönyvet, esetleg a társaság közlönyét, s más kiadványait; köt szerződést a nyomdákkal; vezeti a helyi lapokban az „Irodalmi tájékoztató” rovatot; gondoskodik az ülések tárgysorozatáról s hírlapilag értesíti a közönséget az ülések és nagygyűlés tartásáról. Kezeli a társaság irattárát. Sürgős és rendkívüli esetekben utólagos felelősség mellett 100 /egyszáz/ koronáig utalványozhat. Részére a közgyűlés a szükséghez képest évi díjat állapíthat meg.

\section{9.§.}

A titkár.

Vezeti a jegyzőkönyveket és tagok jegyzékét, kezeli a társaság könyvtárát. A főtitkárt szükség esetén mindenben helyettesíti.

A jegyzőkönyveket egy héten belül elkészíteni s hitelesítve a fötitkárnak beszolgáltatni köteles. 
A titkárt a jegyzőkönyvek vezetésében akadályoztatása esetén a jelenlevő legfiatalabb rendes tag helyettesíti.

20.§.

A pénztáros

A pénztáros kezeli a társaság pénzét, beszedi a tagsági díjakat; a pénztár állásáról minden zárt ülésen jelentést tesz. Számadásait a társaság minden félévben átvizsgáltatja.

A pénztáros csak az elnök és főtitkár által együttesen utalványozott fizetéseket eszközölheti. Ezen egyikének utalványait csak a 17. és 18. szakaszokban körülírt korlátok között fogadja el és fizeti ki.

Részére a közgyűlés szükséghez képest évi díjat állapíthat meg.

21.§.

Az ellenőr

AZ ellenőr a pénztár kezelését ellenőrzi s annak állásáról félévenként jelentést tesz.
22.§.

Az ügyész.

Az ügyész a bíróságok és hatóságok előtt a társaság jogi képviselője.

\section{3.§.}

Az alapszabály megváltoztatása és a társaság feloszlása.

E két tárgyban a külön célból összehívott rendkívüli közgyűlés határoz $s$ a határozat érvényességéhez az az alapszabály megváltoztatása kérdésében a megjelent szavazattal bírók kétharmada, - a feloszlás kérdésében pedig az összes szavazattal bíró tagok háromnegyedének hozzájárulása szükséges.

Ily határozatokat foganatosítás előtt a m. kir. belügyminiszterhez fel kell terjeszteni.

Ha a társaság a jelen alapszabályban meghatározott kört átlépné, azt a m. kir. kormány a felfüggesztés után elrendelendő vizsgálat eredményéhez képest az alapszabályok megtartására külömbeli feloszlatás terhe mellett kötelezheti, esetleg fel is oszlathatja. -

Kelt Kaposvárott, 1904. évi hó n. [A datálás hiányzik! G.F.]

\section{Dr. Pete Márton főtitkár}

\author{
Roboz István \\ elnök
}

\author{
Dr. Kohlbach Bertalan \\ titkár
}

Szám: 77565/1904. III.a

Látta a $\mathrm{m}$. kir belügyminiszter

Budapest, 1904. augusztus hó 18

Hátoldalon ceruzával írt feljegyzés:

Ujjáalakult 1925. évi szept. 24.

Ujjáalakulás utáni címe: „Berzsenyi Dániel Irodalmi és Művészeti Társaság”.

Jóváhagyási száma: 270661/1926 VII.

Hivatkozása:

MNL SML. 20759 szám Somogyvármegye Alispáni iratok 


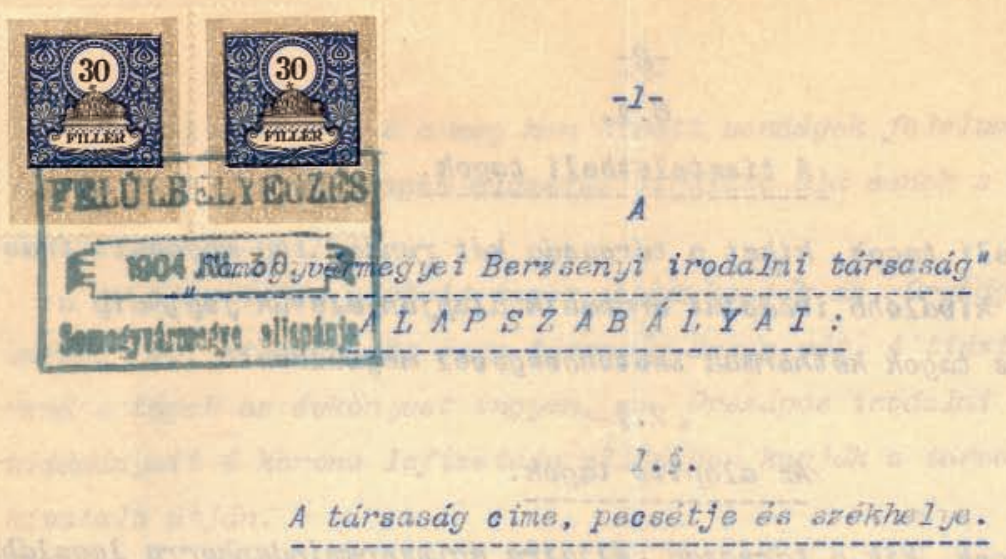

A tirvascig cine: "Sonogyuámegyei Berzsenyi irodalni társaság".

Pecsétje: Sonogjuamegye cimere köril a követkeró sravak: "Sonogyvaimegyei Berrsenjyi irodalni tairsasaig 1904. - Srékhe Iye: Kaposvair.

$$
\text { 2. .. }
$$

A tainsasióg célia:

A társaság célia Berssenyi Dániel és. Sonocynaineqye nás jelcseiemlékének ápoldisa: a magyar szépirodialon, szépmutan, szónoklat és tuciomeiny muvelése és terjesatése; a somogyvinnegyoi népköltés g jung yeinak nüjjtése és a népélet összes. megnyilvármlisainak megörzése an utókor ssánára: bizalnas közeleiést hosni létre az irodalon nunkiabi és a sacl Ieni mrinkcit megbecsïlni tudó kösunsénközött.

$$
\text { 3.5. }
$$

\section{A cél essköseí.}

Srépirodalni, tudományos és srépmitani tárgya felo lvasaisok, irodalmi ünnepélyek rendesése: jelosebs irocalmi temrékek és évkounju ki-

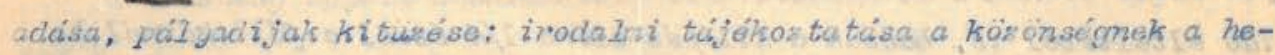
Iji lapok, esetiegia társasaig sajiat köslönje utiain: Uoyaneren ar ston. való irainyitcisa a szinhaigi elóaciásoknak.

$$
\text { 4. } 5 \text {. }
$$

1. A társascic tagul belóp at Oruzagoa irodalni szövetségbe a egy rendes tagjat kilkuldi a ssövetség villass tnkinyeibe.

$$
\begin{gathered}
5.5 \text {. } \\
\text { A tcirscisais tagiai. }
\end{gathered}
$$

A. társaság tagjai: tissteletbeliek, alay itók, rendesek ée j cir to lók.

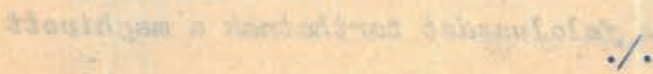

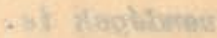




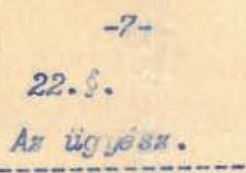

Az ügyész biróscigok és hatóaćgok elótt a társaság jogi képviselöjo. 23. \&.

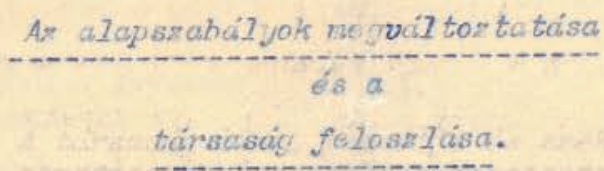

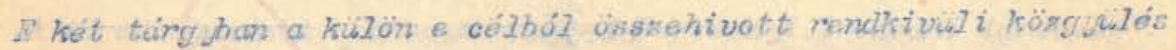

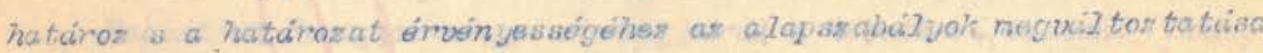

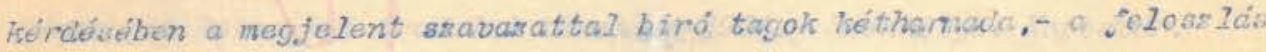
kérdésében pedig as össaes ssavasattal biró tagok hairorbreyjeclének hot-

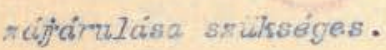

I1y hotairozatokat foganatositais clott a n.kir. Belligyninisterhen $f \in I I$ keII terjeszteni.

$$
\text { Az cillar felingyeleti joga. }
$$

Ha a tcirsascig a jelon clapsrahil jokhan neghatioirosott kört citlépné, ast a m.kir. komichy a felfuggess tés utain elrendelenció vissgálat eredménjeihes képest as alapszabciljals negturtaiscira kiblönheni feloszlatás terhe mellett kotelesheti, esetleg $j \in I$ is osr lathetia.-
KeIt Kaposvárott, 1904.ovi
hó $n$,
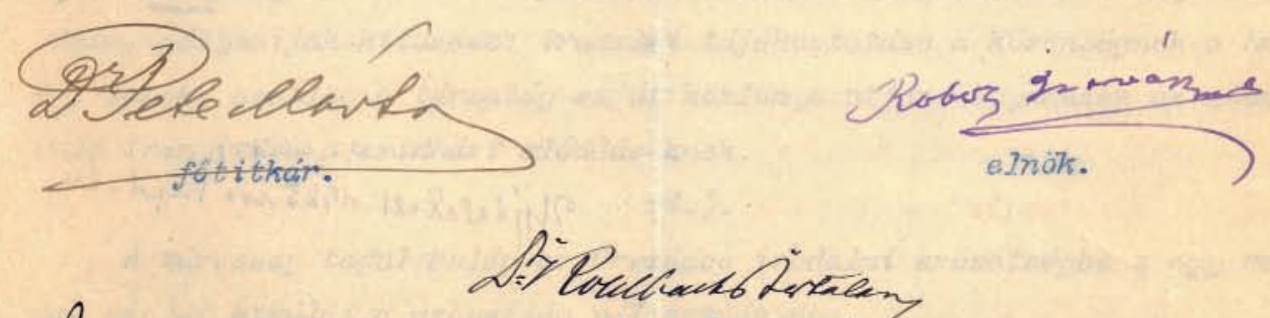

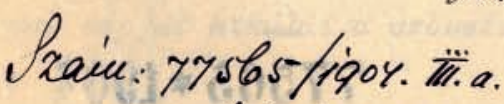

Lóeld a u. vir. belïqyusicister.
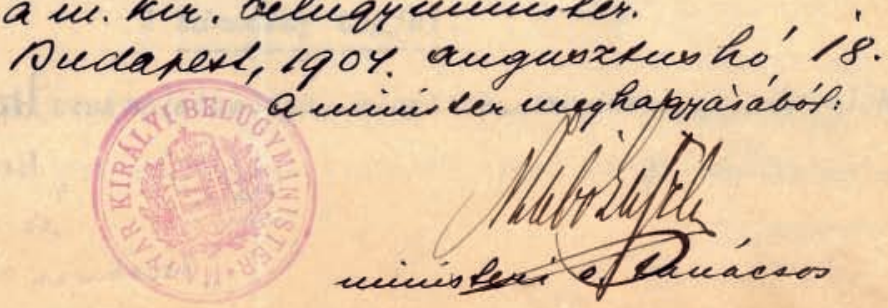
A Berzsenyi irodalmi társaság díszülésének programja, 1904. október 23.

Elnöki megnyitó (Roboz István)

Rákosi Jenő beszéde

Szalay Fruzina mond el három verset

Endrei Ákos olvas fel részletet Berzsenyi tanulmányából: Berzsenyi egyénisége és költészete címmel

Kohlbach Bertalan felolvassa a beérkezett üdvözlő táviratokat és leveleket:

\author{
Berzeviczy miniszter sürgönye, \\ Irodalmi társaságok sürgönyei, \\ Erdélyi Irodalmi Társaság, \\ Országos Irodalmi Társaság, \\ Temesvári Arany János Társaság, \\ Szegedi Dugonics Társaság, \\ Debreceni Csokonai Kör
}

\section{A tagság névsora 1904. május 15.}

A rendes tagok: dr. Andorka Elek, dr. Berzsenyi Gerő, Csertán Márton, dr. Csonka Ede, Danka István, Danilovics János, Dömény József, Endrei Ákos, Faragó Lajos, Herzog Manó, dr. Hollósy István, Horváthné Szaák Lujza, dr. Horváth József, Kacskovics Géza, Karácsonyi Aladár, Kisfaludy Atala, dr. Kohlbach Bertalan, Kondor József, dr. Kriszt Béla, Melhárd Gyula, Mihalik Gyula, Németh István, Noszlopy Tivadar, Obetkóné Szalay Fruzina, Poór Sándor, Psik Andor, Roboz István, dr. Rózsa Ernő, dr. Pete Márton, Szalay Károly, Szalóky Dániel, dr. Szőke Lőrinc, dr. Vass Miklós, Végh Endre, Véniss Károly, dr. Zimmer József. Később: Papp János, Pekár Gyula, dr. Szabó Kálmán, Vikár Béla
Tiszteletbeli tagok: Gárdonyi Géza, Kisfaludy Atala, Pekár Gyula, Rákosi Jenő. Később: Kiss József (18431921) költő, a Hét címủ lap alapító szerkesztője, a Kisfaludy és a Petőfi Társaság tagja, Endrődi Sándor (18501920) költő, újságíró, a Kisfaludy Társaság rendes, az MTA levelező tagja.

Alapító tagok: Berzsenyi Sándor (Nikla), dr. Kacskovics Kálmán, gr. Széchenyi Aladár, gr. Széchenyi Imre.

Támogató tagok: dr. Csorba Ede kir. tanácsos, Takarékpénztári igazgató, Kacskovics Géza és Kapotsfy Jenő országgyűlési képviselők.

\section{A felolvasások időpontja és a felolvasók}

\begin{tabular}{|c|c|c|c|}
\hline 1904. október: & Endrei Ákos, Szalay Fruzina & 1905. május: & $\begin{array}{l}\text { dr. Andorka Elek, Hollósi István, } \\
\text { dr. Vass Miklós }\end{array}$ \\
\hline 1904. december: & Dakos István, Mellhard Gyula & & \\
\hline 1905. január: & Roboz István, Pete Márton & 1905. október: & Végh Endre \\
\hline 1905. március: & Papp János, dr. Kohlbach Bertalan & 1906. február: & Pekár Gyula, Vikár Béla \\
\hline
\end{tabular}

